\title{
Antioxidant and anti-inflammatory activities of selected Chinese medicinal plants and their relation with antioxidant content
}

Anjaneya S Ravipati ${ }^{1}$, Lin Zhang ${ }^{1}$, Sundar Rao Koyyalamudi ${ }^{1,2 *}$, Sang Chul Jeong ${ }^{1}$, Narsimha Reddy ${ }^{1}$, John Bartlett ${ }^{1}$, Paul T Smith', Kirubakaran Shanmugam ${ }^{3,4}$, Gerald Münch ${ }^{3}$, Ming Jie Wu', Manavalan Satyanarayanan ${ }^{5}$ and Balaram Vysetti ${ }^{5}$

\begin{abstract}
Background: The main aim of this study is to evaluate the antioxidant and anti-inflammatory properties of forty four traditional Chinese medicinal herbal extracts and to examine these activities in relation to their antioxidant content.

Methods: The antioxidant activities were investigated using DPPH radical scavenging method and yeast model. The anti-inflammatory properties of the herbal extracts were evaluated by measuring their ability to inhibit the production of nitric oxide and TNF-a in RAW 264.7 macrophages activated by LPS and IFN- $\gamma$, respectively. The cytotoxic effects of the herbal extracts were determined by Alomar Blue assay by measuring cell viability. In order to understand the variation of antioxidant activities of herbal extracts with their antioxidant contents, the total phenolics, total flavonoids and trace metal (Mg, Mn, Cu, Zn, Se and Mo) quantities were estimated and a correlation analysis was carried out.

Results: Results of this study show that significant levels of phenolics, flavonoids and trace metal contents were found in Ligustrum lucidum, Paeonia suffuticosa, Salvia miltiorrhiza, Sanguisorba officinalis, Spatholobus suberectus, Tussilago farfara and Uncaria rhyncophylla, which correlated well with their antioxidant and anti-inflammatory activities. Some of the plants displayed high antioxidant and anti-inflammatory activities but contained low levels of phenolics and flavonoids. Interestingly, these plants contained significant levels of trace metals (such as Zn, Mg and Se) which are likely to be responsible for their activities.
\end{abstract}

Conclusions: The results indicate that the phenolics, flavonoids and trace metals play an important role in the antioxidant activities of medicinal plants. Many of the plants studied here have been identified as potential sources of new antioxidant compounds.

Keywords: Antioxidant activities, Anti-inflammatory properties, Phenolics, Flavonoids, Trace metals

\section{Background}

It is well known that reactive oxygen species (ROS), such as superoxide anion $\left(\mathrm{O}_{2}^{*-}\right)$, hydroxyl radicals $\left(\mathrm{OH}^{*}\right)$, singlet oxygen $\left({ }^{1} \mathrm{O}_{2}\right)$ and hydrogen peroxide $\left(\mathrm{H}_{2} \mathrm{O}_{2}\right)$, play a major role in the development of oxidative stress that can lead to many illnesses including cardiovascular diseases, diabetes, inflammation, degenerative diseases, cancer, anemia, and ischemia [1]. Many synthetic antioxidant agents have been

\footnotetext{
* Correspondence: s.koyyalamudi@uws.edu.au

${ }^{1}$ School of Science and Health, Locked Bag 1797, Penrith South DC NSW 1797, Australia

${ }^{2}$ Centre for Complementary Medicine Research, Locked Bag 1797, Penrith South DC NSW 1797, Australia

Full list of author information is available at the end of the article
}

developed to remediate oxidative stress. However, the factors such as high cost, lack of availability and side effects remained as major setbacks in combating oxidative stress. In this direction, natural antioxidants received a prominence as they are often free from side effects, less expensive and abundant in many plant sources [1]. Plant based antioxidant compounds [1,2] play a defensive role by preventing the generation of free radicals and hence are extremely beneficial to alleviate the diseases caused by oxidative stress [3,4]. Many investigations revealed that phenolics and flavonoids content [1,5-10] contribute to the antioxidant activities of plants. In addixtion to these classes of organic compounds,

\section{Biomed Central}


recent studies demonstrated that trace metals such as $\mathrm{Cu}, \mathrm{Zn}, \mathrm{Mg}, \mathrm{Mn}$ and Se play a beneficial role in antioxidant mechanism $[11,12]$.

Studies have also uncovered that phenolics and flavonoids act as excellent anti-inflammatory agents $[6,13]$. The anti-inflammatory properties of flavonoids have been extensively studied and beneficial effects have been demonstrated in many animal models [13]. Excess production of pro-inflammatory molecules such as TNF- $\alpha$ and nitric oxide (NO) are believed to be responsible for modulating inflammation besides their crucial role in immune-inflammatory response. These inflammatory molecules are also known to cause cell death and tissue damage because NO can react with the free radicals such as superoxides to produce peroxynitrite, that can lead to irreversible damage to cell membranes $[14,15]$. In order to search for effective natural antioxidants and anti-inflammatory compounds, current study has selected forty four traditional Chinese medicinal (TCM) plants based on their ethno-pharmacological importance.

TCM plants have history of usage in the treatment of several diseases for thousands of years [16,17]. They are used for the treatment of many ailments including cancer in China and around the world. Several compounds derived from the TCM plants are potential anticancer agents and many of them are currently in clinical trials [18]. The extracts of TCM herbs are also used as pharmaceutical and dietary supplements.

The most important aspect of natural product research is to select a rapid, easy and efficient screening method. In the current study, the antioxidant activities of selected TCM plants were evaluated using DPPH (diphenylpicrylhydrazyl) radical scavenging method and yeast based antioxidant screening assay [19]. DPPH is a stable synthetic free radical and has been widely used for measuring free radical scavenging activity [20]. The yeast based biological assay detects antioxidant activities of samples against physiologically relevant oxidants. It is believed that antioxidant activities of medicinal plants must be evaluated by more than one method (by at least two methods) in order to take into account different modes of action of a given antioxidant [21]. Hence, in this study the antioxidant and anti-inflammatory activities of selected TCM plants were measured systematically using a series of assays.

\section{Methods}

\section{Plant materials}

The dried plant materials were obtained from Beijing Tong Ren Tang Chinese Herbal Medicine shop, Sydney, Australia. A voucher specimen of each plant has been deposited in the laboratory. The scientific names and family names were given in Table 1 . The plant materials were ground to a fine powder in a grinder before extraction.

\section{Chemicals and reagents}

Gallic acid, Quercetin, 2, 2-diphenyl-1-picrylhydrazyl (DPPH), Dimethyl sulfoxide (DMSO), sodium carbonate, aluminium chloride $\left(\mathrm{AlCl}_{3}\right)$, sodium nitrate $\left(\mathrm{NaNO}_{2}\right)$, sodium hydroxide $(\mathrm{NaOH})$, hydrogen peroxide $\left(\mathrm{H}_{2} \mathrm{O}_{2}\right)$, Folin-Ciocalteu (F-C) reagent, ascorbic acid, 95\% ethanol, bovine serum albumin (BSA), lipopolysaccharide (LPS: E.coli serotype 0127:B8), N-(1-1napthyl) ethylenediamine dihydrochloride, penicillin G sodium benzyl, resazurin sodium $10 \%$, streptomycin, sulfanilamide, tetramethyl benzidine (TMB), trypan blue were purchased from Sigma (Australia) and Lomb Scientific Pty Ltd (Australia). Antibiotics, Dulbecco's modified eagle's medium (DMEM), foetal bovine serum (FBS) and glutamine were purchased from GIBCO. Interferon- $\gamma$ (murine) and tumor necrosis factor- $\alpha$ (TNF- $\alpha$ ) - enzyme-linked immunosorbent assay (ELISA) kits were purchased from Peprotech. RAW 264.7 macrophages (ATCC number TIB-71) were obtained from American Type Culture Collection (ATCC).

\section{Preparation of water extracts}

Approximately $3 \mathrm{~g}$ of each grounded plant material was autoclaved with $30 \mathrm{~mL}$ of deionised water at $121^{\circ} \mathrm{C}$ for $1 \mathrm{hr}$ as described in a previous publication [6]. The extracted samples were centrifuged at $10,447 \mathrm{~g}$ for $20 \mathrm{~min}$ ) and the supernatant was transferred into a $50 \mathrm{~mL}$ volumetric flask. The residue was further rinsed two more times, pooled the extracts and the volume adjusted to $50 \mathrm{~mL}$. The samples were stored at $-20^{\circ} \mathrm{C}$ until analysis.

\section{Preparation of ethanol extracts}

Ground samples $(3 \mathrm{~g})$ were extracted with $30 \mathrm{~mL}$ of $95 \%$ ethanol on water bath at $70^{\circ} \mathrm{C}$ for $6 \mathrm{hr}$ [6]. The extracted samples were centrifuged and the supernatant was transferred into a $50 \mathrm{~mL}$ volumetric flask. The residue was further rinsed two more times, pooled the extracts and the volume adjusted to $50 \mathrm{~mL}$ with $95 \%$ ethanol. The samples were stored at $-4^{\circ} \mathrm{C}$ until analysis. All water and ethanol extracts were filtered before analysis.

\section{Determination of total phenolic content}

The total phenolic content was determined by FolinCiocalteu (F-C) colorimetric method [43]. Briefly, $50 \mu \mathrm{L}$ of sample and $50 \mu \mathrm{L}$ of $\mathrm{F}-\mathrm{C}$ reagent were pipetted into an eppendorf tube. The contents were vortexed for $10 \mathrm{sec}$ and then left at room temperature for $2 \mathrm{~min}$. After $2 \mathrm{~min}, 500 \mu \mathrm{L}$ of $5 \%(\mathrm{w} / \mathrm{v})$ sodium 
Table 1 List of Chinese medicinal herbs used in this study

\begin{tabular}{|c|c|c|c|c|c|}
\hline S. no & Name of the plant species & Chinese name & Family names & Traditional medicinal use & References \\
\hline 1 & Acanthopanax senticosus Herms & NA & Araliaceae & $\begin{array}{l}\text { Treatment of rheumatism, allergies } \\
\text { and diabetics }\end{array}$ & [22] \\
\hline 2 & Actinidia arguta (Sieb.et Zucc.)Flarich.ex Miq. & Teng li gen & Actinidiaceae & Anticancer and anti-allergic & [23] \\
\hline 3 & Akebia quinata (Houtt.)Decne. & Ba yue zha & Lardizabalaceae & anti-phlogistic & [24] \\
\hline 4 & Alpinae officinarum & Gao liang jiang & Zingaberaceae & Antioxidant & [25] \\
\hline 5 & Andrographis paniculata (Burm.f.) Wall. ex Nees & Shuan xin lian & Acanthaceae & Anti-cacner. & [26] \\
\hline 6 & Artemisia vulgaris $L$. & Ai ye & Asteraceae & Anti-cancer & [27] \\
\hline 7 & Asparagus cochinchinensis (Lour.) Merr. & Tian men dong & Asparagaceae & Anti-tumour & [28] \\
\hline 8 & Aster tataricus L. & Zi wan & Asteraceae & Anti-oxidant & [29] \\
\hline 9 & Corydalis yanhusuo W. & Yan hu suo & Papaveraceae & Anti-cancer & [18] \\
\hline 10 & Curcuma zedoaria (Christm.) Roscoe & E zhu & Zingiberaceae & $\begin{array}{l}\text { Antioxidant activity, Anti-mutagenic } \\
\text { activity and Anti-microbial activity, }\end{array}$ & [30] \\
\hline 11 & Cynanchum paniculatum (Bge.) Kitag & Xu chang qing & Asclepiadaceae & Anticancer & [18] \\
\hline 12 & Cyperus rotundus L. & Xiang fu & Cyperaceae & Anticancer & [18] \\
\hline 13 & Ducheshea indica (Andr.) Focke. & She mei & Rosaceae & Anti-inflammatory and anti-cancer & [31] \\
\hline 14 & Hedyotis diffusa Willd. & Bai hua she she cao & Rubiaceae & Antibacterial & [18] \\
\hline 15 & Leonurus japonicus Houtt. & Yi mu cao & Labiatae & Anti-cancer & [32] \\
\hline 16 & Ligustrum lucidum Ait. & Nv zhen zi & Moraceae & Anti-cancer & [18] \\
\hline 17 & Lobelia chinensis Lour. & Ban bian lian & Campanulaceae & $\begin{array}{l}\text { Antipyretic, anti-inflammatory, } \\
\text { and antitoxic effects }\end{array}$ & [18] \\
\hline 18 & Lysinachia christinae Hance. & Jin qian cao & Lysimachia & Anticancer & [18] \\
\hline 19 & Paeonia lactiflora Pall. & Bai shao & Paeoniaceae & Anticancer and anti-bacterial & [33] \\
\hline 20 & Paeonia suffuticosa Sndr. & Mu dan pi & Ranunculaceae & Anti-cancer & [18] \\
\hline 21 & Paris polyphylla Smith & Qi ye yi zhi hua & Trilliaceae & Anti-tumour & [28] \\
\hline 22 & Platycodon grandiflorus (Jacq.) A. DC. & Jie geng & Campanulaceae & Anti-cancer & [18] \\
\hline 23 & Plantago asiatica L. & Che qian cao & Plantaginaceae & Anti-cancer & [34] \\
\hline 24 & Pleione bulbocadioides (Franch.)Rolfe. & Shen ci gu & Orchidaceae & Anticancer and antibacterial & [18] \\
\hline 25 & Ploygala tenuifolia Willd. & Yuan zhi & Polygalaceae & Anti- inflammatory & [35] \\
\hline 26 & Polygonum aviculare L. & Bian cun & Polygonaceae & $\begin{array}{l}\text { Anti-oxidant activity and } \\
\text { anti- inflammatory activity }\end{array}$ & {$[36]$} \\
\hline 27 & Poria cocos (Schw.) Wolf & Fu lin & Polyporaceae & Anti-tumuor & [28] \\
\hline 28 & Pogostemon cablin Benth. & Guang huo xiang & Asteraceae & $\begin{array}{l}\text { Anti-insecticidal, anti-fungal and } \\
\text { bacteriostatic }\end{array}$ & [37] \\
\hline 29 & Prunella vulgaris $\mathrm{L}$. & Xia ku cao & Lamiaceae & $\begin{array}{l}\text { Anticancer and anti-inflammatory } \\
\text { properties }\end{array}$ & [38] \\
\hline 30 & $\begin{array}{l}\text { Pseudostellaria heterophylla (Miq.) Pax ex } \\
\text { Pax et Hoffm. }\end{array}$ & Tai zi shen & Caryophyllaceae & Anti-tumuor & [28] \\
\hline 31 & Rabdosia rubescens(Hamst.)Wuet. & Dong ling cao & Labiatae & Anti-cancer & [18] \\
\hline 32 & Rehmannia glutinosa (Gaertn.) Steud. & Sheng di huang & Phrymaceae & Anti-tumour & [28] \\
\hline 33 & Salvia miltiorrhiza Bunge. & Dan shen & Caspase & Anti-tumuor & [28] \\
\hline 34 & Sanguisorba officinalis $L$. & Di yu & Rosaceae & Anti-allergic and hepatitis B virus & [18] \\
\hline 35 & Schizandra chinensis (Turcz.) Baill. & Wu wei zi & Schisandraceae & Antioxidant effect & [39] \\
\hline 36 & Scutellaria barbata Don. & Ban zhi lian & Labiatae & Anti-tumuor & [28] \\
\hline 37 & Semen coicis $\mathrm{L}$. & Yi yi ren & Gramineae & Anti-cancer & [18] \\
\hline 38 & Smilax glabra Roxb. & Tu fu ling & Smilacaceae & Anti-tumuor & [28] \\
\hline 39 & Solanum nigrum L. & Long Kui & Solanaceae & Anti-cancer & [18] \\
\hline
\end{tabular}


Table 1 List of Chinese medicinal herbs used in this study (Continued)

\begin{tabular}{|c|c|c|c|c|c|}
\hline 40 & Solanum lyratum Thunb. & Bai ying & Solanaceae & Anti-tumuor & [28] \\
\hline$x 41$ & Spatholobus suberectus Dunn. & Ji xie teng & Leguminosae & Anti-tumuor & [18] \\
\hline 42 & Tussilago farfara $\mathrm{L}$. & Kuan dong & Asteraceae & Anti-microbialand antioxidant & [40] \\
\hline 43 & Uncaria rhyncophylla Miq & Gou Teng & Rubiaceae & $\begin{array}{l}\text { Antioxidant activity and } \\
\text { anti-inflammatory activity }\end{array}$ & [41] \\
\hline 44 & Viscum coloratum (Komar.) Nakai & Hui ji sheng & Viscaceae & Anti-infammatory & [42] \\
\hline
\end{tabular}

NA:No appropriate reference is available.

carbonate solution was added to stop the reaction and then $400 \mu \mathrm{L}$ of distilled water was added to make up to $1 \mathrm{~mL}$. The vortexed reaction mixture was heated in a water bath at $45^{\circ} \mathrm{C}$ for $30 \mathrm{~min}$ and then cooled rapidly in an ice bath. Absorbance was measured at $760 \mathrm{~nm}$. Gallic acid concentrations ranging from 0-300 $\mu \mathrm{g} / \mathrm{mL}$ were prepared and the calibration curve was obtained using a linear fit $\left(r^{2}=0.9961\right)$. The samples were analyzed in duplicates.

\section{Determination of total flavonoid content}

The total flavonoid content was estimated by aluminium chloride method [44]. Briefly, $0.5 \mathrm{~mL}$ of each sample and $300 \mu \mathrm{L}$ of $\mathrm{NaNO}_{2}(1: 20 \mathrm{w} / \mathrm{v})$ were pipetted into a test tube. The contents were vortexed for $10 \mathrm{sec}$ and left at room temperature for $5 \mathrm{~min}$. Into the mixture were then added $300 \mu \mathrm{L}$ of $\mathrm{AlCl}_{3}(1: 10 \mathrm{w} / \mathrm{v}), 2 \mathrm{~mL}$ of $1 \mathrm{M} \mathrm{NaOH}$ and $1.9 \mathrm{~mL}$ of distilled water. After vortexing for $10 \mathrm{sec}$, the absorbance for each sample was measured at 510 $\mathrm{nm}$. Quercetin concentrations ranging from 0 to $1200 \mu \mathrm{g} / \mathrm{mL}$ were prepared and the standard calibration curve was obtained using a linear fit $\left(r^{2}=0.9980\right)$. The samples were analyzed in duplicates.

\section{Determination of trace metal content using ICP-MS technique}

The plant water extracts were digested with $5 \mathrm{~mL}$ of concentrated $\mathrm{HNO}_{3}$ (Suprapure, Merck) and $2 \mathrm{~mL}$ of $\mathrm{H}_{2} \mathrm{O}_{2}$ (Suprapure, Merck) in a clean glass beaker and heated on a hot plate and diluted to $10 \mathrm{~mL}$ with double deionized water (Milli-Q Millipore 18.2 MW/ $\mathrm{cm}$ resistivity). A blank digest was also carried out in the same way. The temperature of the hot plate was maintained at around $105^{\circ} \mathrm{C}$ continuously for 4-5 hr in order to completely digest the sample and to sustain recovery of volatile elements. The concentration of six elements, namely $\mathrm{Mg}, \mathrm{Mn}, \mathrm{Cu}, \mathrm{Zn}$, Se and Mo, were measured by inductively coupled plasma-mass spectrometer (ICP-MS) (Model: Perkin Elmer ${ }^{\circledR}$ ELAN DRC II, Ontorio, Canada). The certified reference material, NIST SRM 1640a was used as a calibration standard and NIST SRM 1643e (obtained from National Institute of Standards \& Technology, NIST,
USA) was analyzed as an unknown along with the samples to ensure accuracy. Triplicate analysis of all the samples was conducted in order to check the precision and accuracy of the data. The overall RSD for all the samples was less than 10, and the standard error was found to be within the required analytical precision. The method has been validated according to the standard ISO guidelines.

\section{Free radical DPPH scavenging assay}

$\mathrm{DPPH}$ radical scavenging assay was carried using Blois method [45]. Each plant extract $(50 \mu \mathrm{L})$ in water and ethanol was added to a $150 \mu \mathrm{L}$ of $62.5 \mu \mathrm{M}$ DPPH. After $30 \mathrm{~min}$ of incubation, the absorbance of the reaction mixtures was measured at $492 \mathrm{~nm}$ using a microplate reader (Multiskan EX, Thermo Electron, USA). Ascorbate (Vitamin C), an antioxidant, was used as a positive control. A standard curve was included for each plate with a series of ascorbate concentrations $(0,10,20,40$, $60,80,100,200,400$ and $1000 \mu \mathrm{M})$. The free radical reduction capacity for each herbal extract was calculated as the ascorbate equivalent against the ascorbate standard curve $\left(r^{2}=0.9924\right)$.

\section{Antioxidant activity screening in a 96-well microplate high throughput assay using Saccharomyces cerevisiae} The antioxidant capacities of the herbal extracts were also measured using a $S$. cerevisiae-based high throughput assay [19]. S. cerevisiae BY4743 were cultured overnight in a $50 \mathrm{~mL}$ volume by inoculation of a single colony. The culture was then diluted to an optical density at $600 \mathrm{~nm}\left(\mathrm{OD}_{600}\right)$ of 0.2 in media, and $180 \mu \mathrm{L}$ of each strain was added into a well in a 96-well microtitre plate where $10 \mu \mathrm{L}$ per well of each herbal extract was also added in duplicates. $10 \mu \mathrm{L}$ of $\mathrm{H}_{2} \mathrm{O}_{2}$ was added to a final concentration of $4 \mathrm{mM}$. The initial $\mathrm{OD}_{600}$ reading was taken using a microplate reader (Multiskan EX, Thermo Electron, USA), and the plates were then incubated in a $30^{\circ} \mathrm{C}$ incubator with shaking at $750 \mathrm{rpm}$. Yeast growth was monitored at reading $\mathrm{OD}_{600}$ at the end of 20 hours. Ascorbic acid was used as a positive control. The net growth of $\mathrm{H}_{2} \mathrm{O}_{2}$ induced yeast cells 
after the treatment of selected plant extracts was measured using the following equation

$$
P_{\text {yeast growth }}=\left(\frac{P_{\text {Sample }}-P_{\text {Control }}}{P_{\text {Control }}}\right) \times 100
$$

' $P_{\text {yeast growth }}=$ Net growth of $\mathrm{H}_{2} \mathrm{O}_{2}$ induced yeast cells after treatment with plant extracts.

' $P_{\text {Sample }}$ = Observed optical density of yeast cells with the treatment of plant extracts.

' $P_{\text {Control }}$ = Observed optical density of yeast cells with the treatment of negative control $\left(\mathrm{H}_{2} \mathrm{O}_{2}\right)$.

\section{Maintenance and activation of RAW 264.7 macrophages}

RAW 264.7 macrophages were grown in $175 \mathrm{~cm}^{2}$ flasks on DMEM containing 5\% FBS that was supplemented with antibiotics (1\%) and glutamine (1\%). The cell line was maintained in $5 \% \mathrm{CO}_{2}$ at $37^{\circ} \mathrm{C}$, with media being replaced every 3-4 days. Once cells had grown to confluence in the culture flask, they were removed using a rubber policeman, as opposed to using trypsin, which can remove membranebound receptors such as RAGE $[6,46]$. Cell suspension was concentrated by centrifuging for $3 \mathrm{~min}$ at $900 \mathrm{rpm}$ and resuspension in a small volume of fresh DMEM (with 1\% antibiotics and 5\% FBS). Cell densities were estimated using a Neubauer counting chamber. Cell concentration is adjusted with DMEM (with 1\% antibiotics and 5\% FBS) to obtain 75,000 cells/well when $100-\mu \mathrm{L}$ cell suspensions dispensed into the 60-inner wells of 96 -well plates. Sterile distilled water was added to the outer row of wells and incubated at $37^{\circ} \mathrm{C} ; 5 \% \mathrm{CO}_{2}$ for $12 \mathrm{hr}$. From each well, conditioned medium was replaced with fresh serum-free medium. For assays with extracts, $50-\mu \mathrm{L}$ volume of the dilutions (in water) was added an hour prior to addition of activator. Due to the often inconsistent nature of LPS at activating cells, a combination of $25 \mu \mathrm{g} / \mathrm{mL}$ LPS and $10 \mathrm{U} / \mathrm{ml}$ IFN- $\gamma$, both in DMEM, was used for activation. Usually a maximum dose of the extracts used was $2.5 \mathrm{mg} / \mathrm{mL}$ and a minimum of 6 doses made by serial dilution. Then the cells were incubated for $24 \mathrm{hr}$ at $37^{\circ} \mathrm{C}$ and $5 \% \mathrm{CO}_{2}$. Cells with media alone were used as negative control and activated cells as positive control.

\section{Determination of nitric oxide production by Griess assay}

Nitric oxide is determined by Griess reagent quantification of nitrite; one of its stable reaction products. Griess reagent is freshly made up of equal volumes of $1 \%$ sulphanilamide and $0.1 \%$ napthyethylene-diamine in $5 \% \mathrm{HCl}$. In the presence of nitrite this reagent forms a violet colour. From each well $70 \mu \mathrm{L}$ of supernatant was transferred to a fresh 96-well plate and mixed with $70 \mu \mathrm{L}$ of Griess reagent and the colour produced was measured at $540 \mathrm{~nm}$. The remaining supernatant that was removed from each well was used for TNF- $\alpha$ assay using a commercial sandwich ELISA.

\section{Determination of cell viability by Alamar Blue assay}

Alamar Blue assay is a calorimetric assay involving the cellular reduction of resazurin to resorufin. $100 \mu \mathrm{L}$ of Alamar Blue solution (10\% Alamar Blue (Resazurin) in DMEM media) was added to each well and incubated at $37^{\circ} \mathrm{C}$ for 1-2 hr. Fluorescence was measured (excitation @ 545 nm and emission @ $595 \mathrm{~nm}$ ) and expressed as a percentage of that in control cells after background fluorescence was subtracted.

\section{TNF- $a$ determination by ELISA}

Sandwich ELISA was used according to the manufacturer's manual (Peprotech) to determine TNF- $\alpha$ concentration. Capture antibody was used at a concentration of $0.5 \mu \mathrm{g} / \mathrm{mL}$ in PBS $\left(1.9 \mathrm{mM} \mathrm{NaH}_{2} \mathrm{PO}_{4}, 8.1 \mathrm{mM} \mathrm{Na}_{2} \mathrm{HPO}_{4}\right.$, $154 \mathrm{mM} \mathrm{NaCl} ; \mathrm{pH}$ 7.4). Serial dilutions of TNF- $\alpha$ standard from 0 to $1000 \mathrm{pg} / \mathrm{mL}$ in diluent $(0.05 \%$ Tween-20, $0.1 \%$ BSA in PBS) were used as internal standard. TNF- $\alpha$ was detected with a biotinylated second antibody and an avidin peroxidase conjugate with TMB as detection reagent. The color development was monitored at $655 \mathrm{~nm}$, taking readings after every $5 \mathrm{~min}$. After $25 \mathrm{~min}$ the reaction was stopped using $0.5 \mathrm{M}$ sulphuric acid and the absorbance was measured at $450 \mathrm{~nm}$.

\section{Data presentation and analysis}

As the experiments were done in duplicates, the results were expressed in mean \pm standard deviation. In addition, linear relationships and significance tests of these data sets were also conducted. GraphPad prism 5.01 was used for growth curve analysis in dose-dependent experiments and to determine the $\mathrm{IC}_{50}$ values for $\mathrm{NO}$ and TNF- $\alpha$ inhibition.

\section{Results and discussion}

\section{Total phenolics and flavonoids content in the selected} plants

The total phenolics and flavonoids content of selected 44 herbal extracts were measured using $\mathrm{F}-\mathrm{C}$ reagent and aluminium chloride methods respectively. These results obtained for water and ethanol extracts of the plants are presented in Table 2.

\section{Water extracts}

As can be seen from Table 2, significant phenolics content was observed in water extracts of S. officinalis $(148.09 \mathrm{GAE}$ $\mathrm{mg} / \mathrm{g})$, S. miltiorrhiza (66.27 GAE $\mathrm{mg} / \mathrm{g}$ ) and moderate levels in U. rhyncophylla (32.38 GAE mg/g), L. lucidum (29.1 GAE mg/g), Ducheshea indica (28.62 GAE mg/g), T. farfara (25.72 GAE mg/g), Artemisia vulgaris (24.91 GAE $\mathrm{mg} / \mathrm{g}$ ) and S. suberectus (24.11 GAE $\mathrm{mg} / \mathrm{g}$ ). High levels of flavonoids content was found in water extracts of S. suberectus (165.16 QE mg/g), S. miltiorrhiza (133.93 QE $\mathrm{mg} / \mathrm{g})$, S. officinalis (129.53 QE mg/g), L. lucidum (108.42 QE mg/g) and moderate to low levels in Artemisia vulgaris 
Table 2 The total phenolics and flavonoids content together with DPPH free radical scavenging activities of ethanol and water extracts of plant material, and the antioxidant activity against yeast oxidative stress

\begin{tabular}{|c|c|c|c|c|c|c|c|}
\hline \multirow[b]{2}{*}{ Name of the plants } & \multicolumn{2}{|c|}{$\begin{array}{l}\text { DPPH scavenging activity } \\
(\mu \mathrm{M} \text { Ascorbate equivalent } / \mathrm{g})^{1}\end{array}$} & \multirow[b]{2}{*}{$\begin{array}{l}\% \text { inhibition of } \\
\text { Yeast oxidation } \\
\text { of water extracts }{ }^{2}\end{array}$} & \multicolumn{2}{|c|}{$\begin{array}{l}\text { Total phenolics content } \\
(\text { GAE } \mathrm{mg} / \mathrm{g})^{3}\end{array}$} & \multicolumn{2}{|c|}{$\begin{array}{l}\text { Total flavonoids content } \\
(\mathrm{QE} \mathrm{mg/g})^{3}\end{array}$} \\
\hline & $\begin{array}{l}\text { Water } \\
\text { extracts }\end{array}$ & $\begin{array}{l}\text { Ethanol } \\
\text { Extracs }\end{array}$ & & $\begin{array}{l}\text { Water } \\
\text { extracts }\end{array}$ & $\begin{array}{l}\text { Ethanol } \\
\text { extracts }\end{array}$ & $\begin{array}{l}\text { Water } \\
\text { extracts }\end{array}$ & $\begin{array}{l}\text { Ethanol } \\
\text { extracts }\end{array}$ \\
\hline Acanthopanax senticosus & $186.9 \pm 0.71$ & $99.93 \pm 1.01$ & 10.11 & $8.52 \pm 3.00$ & $3.89 \pm 0.00$ & $24.21 \pm 0.98$ & $14.37 \pm 0.00$ \\
\hline Actinidia arguta & $183.4 \pm 1.41$ & $104.21 \pm 0$ & 7.24 & $4.71 \pm 0.55$ & $15.26 \pm 0.44$ & $13.99 \pm 0.98$ & $62.85 \pm 0.98$ \\
\hline Akebia quinata & $195.4 \pm 1.41$ & $99.93 \pm 4.04$ & 14.76 & $7.09 \pm 4.64$ & $8.22 \pm 0.44$ & $16.66 \pm 1.96$ & $41.4 \pm 5.87$ \\
\hline Alpinae officinarum & $201.9 \pm 0.71$ & $105.29 \pm 0.51$ & 0 & $11.78 \pm 0.00$ & $23.35 \pm 3.14$ & $26.81 \pm 0.98$ & $87.39 \pm 0.98$ \\
\hline Andrographis paniculata & $171.4 \pm 1.41$ & $76.00 \pm 4.55$ & 13.33 & $5.09 \pm 0.41$ & $1.92 \pm 1.03$ & $8.94 \pm 0.98$ & $7.22 \pm 1.96$ \\
\hline Artemisia vulgaris & $181.9 \pm 0.71$ & $98.14 \pm 1.52$ & 5.32 & $24.91 \pm 0.27$ & $7.43 \pm 1.44$ & $79.68 \pm 1$ & $16.43 \pm 3.91$ \\
\hline Asparagus cochinchinensis & $55.9 \pm 12.02$ & $5.64 \pm 1.01$ & 16.37 & $2.67 \pm 0.96$ & $0.91 \pm 3.01$ & $1.71 \pm 0.98$ & $1.08 \pm 0.98$ \\
\hline Aster tataricus & $119.4 \pm 2.83$ & $49.93 \pm 2.02$ & 0 & $15.17 \pm 0.27$ & $6.95 \pm 0.00$ & $39.82 \pm 0.98$ & $22.79 \pm 0.98$ \\
\hline Corydalis yanhusuo & $39.9 \pm 0.71$ & $42.43 \pm 5.56$ & 14.81 & $3.51 \pm 1.36$ & $1.28 \pm 1.48$ & $1.57 \pm 0.96$ & $2.11 \pm 0.98$ \\
\hline Curcuma zedoaria & $158.9 \pm 0.71$ & $108.14 \pm 1.52$ & 10.98 & $6.14 \pm 0.55$ & $7.38 \pm 0$ & $11.67 \pm 0.98$ & $25.38 \pm 2.93$ \\
\hline Cynanchum paniculatum & $138.9 \pm 0.71$ & $32.79 \pm 1.01$ & 6.13 & $6.31 \pm 0$ & $3.05 \pm 0.89$ & $3.3 \pm 0$ & $10.03 \pm 0.00$ \\
\hline Cyperus rotundus & $114.9 \pm 4.95$ & $85.29 \pm 2.53$ & 5.06 & $3.46 \pm 0.82$ & $1.89 \pm 0.44$ & $5.01 \pm 0.98$ & $17.97 \pm 0.98$ \\
\hline Ducheshea indica & $202.4 \pm 1.41$ & $102.07 \pm 4.04$ & 2.34 & $28.62 \pm 0.68$ & $11.8 \pm 0.44$ & $22.31 \pm 4.89$ & $15.25 \pm 1.96$ \\
\hline Hedyotis diffusa & $160.9 \pm 6.36$ & $42.79 \pm 2.02$ & 8.54 & $5.17 \pm 0.27$ & $2.25 \pm 0.00$ & $7.37 \pm 1.96$ & $8.5 \pm 0.98$ \\
\hline Leonurus japonicus & $159.9 \pm 0.71$ & $41.36 \pm 4.04$ & 1.93 & $6.46 \pm 0.82$ & $0.84 \pm 2.66$ & $8.22 \pm 1.96$ & $5.39 \pm 1.96$ \\
\hline Ligustrum lucidum & $194.9 \pm 0.71$ & $107.79 \pm 0$ & 12.02 & $29.1 \pm 3.28$ & $19 \pm 0.78$ & $108.42 \pm 1.96$ & $24.88 \pm 0.98$ \\
\hline Lobelia chinensis & $101.4 \pm 0$ & $12.79 \pm 2.02$ & -1.94 & $4.59 \pm 0.14$ & $2.74 \pm 0.44$ & $2.79 \pm 0.98$ & $8.92 \pm 3.91$ \\
\hline Lysinachia christinae & $193.9 \pm 3.54$ & $66.00 \pm 0.51$ & 0 & $4.24 \pm 0.55$ & $3.91 \pm 0.30$ & $2.63 \pm 1.96$ & $10.29 \pm 0.00$ \\
\hline Paeonia lactiflora & $172.9 \pm 3.54$ & $113.14 \pm 0.51$ & 16.46 & $7.65 \pm 0.41$ & $6.3 \pm 0.44$ & $3.39 \pm 1.96$ & $6.42 \pm 0.98$ \\
\hline Paeonia suffuticosa & $200.4 \pm 0.00$ & $111.71 \pm 0.51$ & 15.16 & $19.96 \pm 1.09$ & $19.74 \pm 0.39$ & $25.85 \pm 1.96$ & $31.40 \pm 2.93$ \\
\hline Paris polyphylla & $19.9 \pm 2.12$ & $45.29 \pm 1.52$ & 0 & $1.23 \pm 1.36$ & $1.01 \pm 3.69$ & $0.72 \pm 1.96$ & $2.60 \pm 1.96$ \\
\hline Platycodon grandiflorus & $30.9 \pm 3.54$ & $14.93 \pm 4.04$ & 21.77 & $4.58 \pm 1.50$ & $0.79 \pm 0.26$ & $2.93 \pm 2.93$ & $1.52 \pm 0.96$ \\
\hline Plantago asiatica & $184.4 \pm 9.9$ & $49.93 \pm 1.01$ & 19.77 & $6.7 \pm 0.96$ & $0.82 \pm 0.39$ & $15.57 \pm 3.91$ & $3.32 \pm 1.96$ \\
\hline Pleione bulbocadioides & $27.4 \pm 7.07$ & $85.64 \pm 1.01$ & 0 & $1.62 \pm 0.27$ & $1.05 \pm 2.51$ & $2.09 \pm 0.98$ & $1.73 \pm 0.98$ \\
\hline Ploygala tenuifolia & $109.4 \pm 2.83$ & $53.14 \pm 2.53$ & 3.23 & $12.01 \pm 0.00$ & $12.15 \pm 0.44$ & $9.3 \pm 3.91$ & $37.55 \pm 3.91$ \\
\hline Polygonum aviculare & $201.4 \pm 2.83$ & $88.86 \pm 1.52$ & 3.67 & $5.9 \pm 0.82$ & $11.72 \pm 0.15$ & $9.15 \pm 0.00$ & $14.15 \pm 0.00$ \\
\hline Poria cocos & $28.9 \pm 3.54$ & $109.57 \pm 0.51$ & 12.11 & $0.45 \pm 0$ & $1.43 \pm 3.53$ & 0 & $0.68 \pm 0.98$ \\
\hline Pogostemon cablin & $103.4 \pm 4.24$ & $26.00 \pm 1.52$ & 12.07 & $4.23 \pm 0.68$ & $1.88 \pm 0.13$ & $5.54 \pm 0.98$ & $4.08 \pm 0.98$ \\
\hline Prunella vulgaris & $106.9 \pm 20.51$ & $106.36 \pm 0.00$ & 0 & $16.02 \pm 0.27$ & $1.66 \pm 0.74$ & $20.27 \pm 3.91$ & $15.62 \pm 1.96$ \\
\hline Pseudostellaria heterophylla & $20.9 \pm 12.02$ & $32.43 \pm 4.55$ & 36.13 & $1.74 \pm 0.82$ & $1.58 \pm 1.83$ & $0.59 \pm 0.00$ & $1.94 \pm 0.98$ \\
\hline Rabdosia rubescens & $144.4 \pm 2.83$ & $13.50 \pm 4.04$ & 8.63 & $17.47 \pm 0.55$ & $2.41 \pm 2.96$ & $40.66 \pm 1.96$ & $8.35 \pm 2.93$ \\
\hline Rehmannia glutinosa & $34.4 \pm 0.00$ & $20.29 \pm 0.51$ & 17.94 & $5.99 \pm 1.23$ & $0.88 \pm 0.13$ & $6.12 \pm 0.98$ & $2.07 \pm 1.96$ \\
\hline Salvia miltiorrhiza & $202.4 \pm 4.24$ & $104.93 \pm 0.00$ & 12.72 & $66.27 \pm 0.14$ & $4.97 \pm 0.15$ & $133.93 \pm 0.98$ & $27.05 \pm 2.93$ \\
\hline Sanguisorba officinalis & $191.9 \pm 0.71$ & $64.21 \pm 2.02$ & -5.47 & $148.09 \pm 2.46$ & $121.42 \pm 0.78$ & $129.53 \pm 0.98$ & $213.23 \pm 0$ \\
\hline Schizandra chinensis & $73.9 \pm 3.54$ & $33.86 \pm 1.52$ & 4.8 & $7.95 \pm 2.73$ & $11.91 \pm 0.15$ & $11.36 \pm 7.82$ & $31.3 \pm 1.96$ \\
\hline Scutellaria barbata & $188.4 \pm 1.41$ & $93.5 \pm 1.01$ & 10.11 & $14.97 \pm 2.73$ & $9.26 \pm 0.15$ & $67.41 \pm 3.91$ & $20.62 \pm 0.98$ \\
\hline Semen coicis & $-100.1 \pm 0.71$ & $11.00 \pm 3.54$ & 12.37 & $0.34 \pm 2.32$ & $1.39 \pm 0.65$ & $0.83 \pm 1.96$ & $16.05 \pm 2.93$ \\
\hline Smilax glabra & $135.9 \pm 2.12$ & $109.21 \pm 0.00$ & 5.84 & $6.19 \pm 2.73$ & $12.62 \pm 0.89$ & $45.28 \pm 1.96$ & $45.95 \pm 4.89$ \\
\hline Solanum nigrum & $190.4 \pm 0$ & $50.64 \pm 3.03$ & 5.17 & $4.2 \pm 0.27$ & $2.98 \pm 2.48$ & $6.43 \pm 0.98$ & $4.41 \pm 4.89$ \\
\hline Solanum lyratum & $192.4 \pm 1.41$ & $47.07 \pm 1.01$ & 1.03 & $3.63 \pm 0.41$ & $2.55 \pm 1.77$ & $2.62 \pm 2.93$ & $5.18 \pm 0.98$ \\
\hline
\end{tabular}


Table 2 The total phenolics and flavonoids content together with DPPH free radical scavenging activities of ethanol and water extracts of plant material, and the antioxidant activity against yeast oxidative stress (Continued)

\begin{tabular}{llllllll}
\hline Spatholobus suberectus & $184.4 \pm 0$ & $98.14 \pm 2.53$ & 10.63 & $24.11 \pm 0.96$ & $34.02 \pm 4.05$ & $165.16 \pm 1.96$ & $69.19 \pm 0.00$ \\
Tussilago farfara & $198.9 \pm 0.71$ & $113.5 \pm 0.00$ & 20.9 & $25.72 \pm 2.87$ & $9.68 \pm 0.15$ & $65.17 \pm 0.98$ & $41.67 \pm 0.98$ \\
Uncaria rhyncophylla & $181.4 \pm 2.83$ & $98.50 \pm 1.01$ & 13.24 & $32.38 \pm 0.55$ & $6.75 \pm 0.30$ & $58.91 \pm 0.00$ & $22.13 \pm 1.96$ \\
Viscum coloratum & $129.9 \pm 12.02$ & $57.07 \pm 0.00$ & 23.69 & $3.34 \pm 3.00$ & $9.06 \pm 0.00$ & $3.07 \pm 0.98$ & $28.58 \pm 3.91$ \\
\hline
\end{tabular}

${ }^{1}$ DPPH free radical scavenging activity was measured in terms of equivalent of ascorbate $(\mu \mathrm{M})$.

${ }^{2}$ Yeast oxidative stress was measured on the basis of survival of yeast cells (yeast growth) after treatment with $\mathrm{H}_{2} \mathrm{O}_{2}$.

${ }^{3}$ Total phenolics and flavonoid contents were expressed in gallic acid equivalent $(\mathrm{GAE} \mathrm{mg} / \mathrm{g})$ and quercetin equivalent (QE mg/g) respectively.

(79.68 QE mg/g), T. farfara (65.17 QE mg/g), U. rhyncophylla (58.91 QE mg/g), Rabdosia rubescens (40.66 QE $\mathrm{mg} / \mathrm{g})$, Aster tataricus (39.82 QE mg/g), Alpinae officinarum (26.81 QE mg/g), Acanthopanaxsenticosus (24.21 QE mg/g) and D. indica (22.31 QE mg/g).

\section{Ethanol extracts}

Amongst all the ethanol extracts, high levels of phenolics content was found in S. officinalis (121.42 GAE mg/g) and moderate levels in S. suberectus (34.02 GAE $\mathrm{mg} / \mathrm{g}$ ) and A. officinarum (23.35 GAE mg/g) (Table 2). High flavonoid content was found in ethanol extracts of $S$. officinalis (213.23 QE $\mathrm{mg} / \mathrm{g})$, A. officinarum (87.39 QE $\mathrm{mg} / \mathrm{g}$ ) and moderate to low levels in S. suberectus (69.10 QE mg/g), Actinidia arguta (62.85 QE mg/g), S. glabra (45.95 QE $\mathrm{mg} / \mathrm{g}$ ), T. farfara (41.67 QE mg/g), Ploygala tenuifolia (37.55 QE mg/g), Paeonia suffuticosa (31.4 QE mg/g) and Viscum coloratum (28.58 QE mg/g).

It is interesting to note that A. officinarum, S. suberectus, S. officinalis, T. farfara, S. miltiorrhiza and U. rhyncophylla have been found to have significant levels of phenolics and flavonoids content in both water and ethanol extracts. A close observation of the results presented in this paper indicates that the total phenolics and flavonoids content varied amongst the selected plant species and in different extracts. These variations of antioxidant contents have been discussed in terms of the observed bioactivities of the plants.

\section{Trace metal content in the selected plants}

In the current study, trace metal content $(\mathrm{Mg}, \mathrm{Mn}, \mathrm{Cu}$, $\mathrm{Zn}$, Se and Mo) of water extracts was determined using ICP-MS technique (Table 3). Among all the metals, Mn was the most abundant while Se and Mo were least abundant. Significant quantity of $\mathrm{Cu}$ was found in Poria $\operatorname{cocos}(230.2 \mu \mathrm{g} / \mathrm{g})$, A. arguta $(201.75 \mu \mathrm{g} / \mathrm{g})$. High levels of $\mathrm{Zn}$ was found in $P . \operatorname{cocos}(1841.43 \mu \mathrm{g} / \mathrm{g}), V$. coloratum $(977.52 \mu \mathrm{g} / \mathrm{g})$, A. arguta $(969.13 \mu \mathrm{g} / \mathrm{g})$ and $S$. officinalis $(909.37 \mu \mathrm{g} / \mathrm{g})$. Of all the analyzed trace metals, Mn was highly abundant in Curcuma zedoaria (2312.15 $\mu \mathrm{g} / \mathrm{g}$ ), U. rhyncophylla (2770.85 $\mu \mathrm{g} / \mathrm{g})$, A. officinarum (2212.53 $\mu \mathrm{g} / \mathrm{g})$, Hedyotis diffusa $(1778.79 \mu \mathrm{g} / \mathrm{g})$, P. cocos $(1257.65$ $\mu \mathrm{g} / \mathrm{g})$ and S. suberectus $(1211.85 \mu \mathrm{g} / \mathrm{g})$. The $\mathrm{Mg}$ content amongst all the plants was relatively high (expressed in $\mathrm{mg} / \mathrm{g}$ in Table 3), while Selenium and Molybdenum were least abundant.

\section{Antioxidant activities}

The antioxidant activities of 44 selected medicinal herbs were evaluated by two methods, namely, DPPH free radical scavenging and yeast based antioxidant screening assay $[19,47,48]$.

The water extracts of S. nigrum, L. lucidum, Polygonum aviculare, S. lyratum, Akebia quinata, S. officinalis, P. suffuticosa, S. miltiorrhiza, A. officinarum, Lysinachia christinae, $D$. indica and $T$. farfara shown significantly high free radical scavenging ability which were more than $190 \mu \mathrm{M}$ ascorbate equiv/g (Table 2). In ethanol extracts, significant DPPH scavenging activity was found in T. farfara, Paeonia lactiflora, P. suffuticosa, P. cocos, S. glabra, C. zedoaria, L. lucidum, Prunella vulgaris, A. officinarum, S. miltiorrhiza, and $A$. arguta, and D. indica which were in the range of $98.14-113.5 \mu \mathrm{M}$ ascorbate equiv/g (Table 2). It is interesting to note that the water extracts have displayed more scavenging activity than the ethanol extracts.

Antioxidant activities of water extracts of the selected plants were also evaluated based on their ability to inhibit the $\mathrm{H}_{2} \mathrm{O}_{2}$ induced yeast oxidative stress (Table 2). These results revealed that the plants Pseudostellaria heterophylla (36.13\%), V. coloratum (23.69\%), Platycodon grandiflorus (21.77\%), T. farfara (20.9\%), Plantago asiatica $(19.77 \%)$ and Rehmannia glutinosa (17.94\%) showed high antioxidant activity. It can be noted from Table 2 that, T. farfara, L. lucidum, P. suffuticosa, S. miltiorrhiza, P. lactiflora and $A$. senticosus have displayed significant antioxidant activity in both DPPH method and yeast model.

\section{Anti-inflammatory activities of plant extracts}

The anti-inflammatory properties of water extracts of the selected medicinal herbs were evaluated on the basis of their ability to inhibit the production of $\mathrm{NO}$ and TNF- $\alpha$ in LPS and IFN- $\gamma$ activated mouse macrophages. Toxicity of the plant extracts was determined using the Alamar Blue assay.

As can be seen from these results (Table 4), the extracts of A. vulgaris, A. arguta, S. officinalis, S. suberectus, $S$. 
Table 3 The trace metal content of water extracts of selected medicinal plants

\begin{tabular}{|c|c|c|c|c|c|c|}
\hline Name of the plants & $\mathrm{Cu}(\mu \mathrm{g} / \mathrm{g})^{*}$ & $\mathrm{Zn}(\mu \mathrm{g} / \mathrm{g})^{*}$ & $M n(\mu g / g)^{*}$ & $M g(m g / g){ }^{\#}$ & Se $(\mu \mathrm{g} / \mathrm{g})^{*}$ & $\operatorname{Mo}(\mu \mathrm{g} / \mathrm{g})^{*}$ \\
\hline Acanthopanax senticosus & $30.86 \pm 0.61$ & $183.33 \pm 3.91$ & $35.01 \pm 0.86$ & $10.35 \pm 0.41$ & $43.04 \pm 1.41$ & $0.73 \pm 0.03$ \\
\hline Actinidia arguta & $201.75 \pm 1.28$ & $969.13 \pm 6.68$ & $182.96 \pm 1.46$ & $38.44 \pm 0.49$ & $5.9 \pm 0.06$ & $2.96 \pm 0.04$ \\
\hline Akebia quinata & $29.28 \pm 1.72$ & $310.65 \pm 19.77$ & $93.36 \pm 6.85$ & $7.24 \pm 0.85$ & $1.74 \pm 0.17$ & $0.12 \pm 0.02$ \\
\hline Alpinae officinarum & $19.94 \pm 0.73$ & $276.02 \pm 10.99$ & $2212.53 \pm 101.6$ & $10.56 \pm 0.78$ & $1.92 \pm 0.12$ & $0.22 \pm 0.02$ \\
\hline Andrographis paniculata & $61.13 \pm 1.77$ & $245.62 \pm 7.69$ & $542.3 \pm 19.6$ & $65.89 \pm 3.81$ & $13.93 \pm 0.67$ & $0.78 \pm 0.05$ \\
\hline Artemisia vulgaris & $43.8 \pm 1.27$ & $135.75 \pm 4.28$ & $321.4 \pm 11.69$ & $18.6 \pm 1.08$ & $16.28 \pm 0.79$ & $0.55 \pm 0.03$ \\
\hline Asparagus cochinchinensis & $6.71 \pm 0.75$ & $77.24 \pm 9.37$ & $54.5 \pm 7.63$ & $3.05 \pm 0.68$ & $1.86 \pm 0.35$ & $0.13 \pm 0.03$ \\
\hline Aster tataricus & $3.47 \pm 0.26$ & $30.35 \pm 2.48$ & $46.6 \pm 4.39$ & $2.78 \pm 0.42$ & $1.44 \pm 0.18$ & $0.09 \pm 0.01$ \\
\hline Corydalis yanhusuo & $7.73 \pm 0.61$ & $154.73 \pm 13.17$ & $42.99 \pm 4.28$ & $9.61 \pm 1.51$ & $0.48 \pm 0.06$ & $0.87 \pm 0.14$ \\
\hline Curcuma zedoaria & $32.74 \pm 0.5$ & $45.85 \pm 0.75$ & $2312.15 \pm 43.84$ & $29.26 \pm 0.89$ & $13.7 \pm 0.35$ & $3.27 \pm 0.1$ \\
\hline Cynanchum paniculatum & $23.57 \pm 0.78$ & $171.76 \pm 6.16$ & $53.96 \pm 2.23$ & $12.39 \pm 0.82$ & $2.92 \pm 0.16$ & $0.51 \pm 0.04$ \\
\hline Cyperus rotundus & $21.03 \pm 0.61$ & $79.54 \pm 2.51$ & $27.35 \pm 0.99$ & $6.41 \pm 0.37$ & $0.54 \pm 0.03$ & $0.39 \pm 0.02$ \\
\hline Ducheshea indica & $18.55 \pm 0.88$ & $175.82 \pm 9.06$ & $156.07 \pm 9.28$ & $19.58 \pm 1.86$ & $2.72 \pm 0.22$ & $0.37 \pm 0.04$ \\
\hline Hedyotis diffusa & $59.23 \pm 1.06$ & $304.91 \pm 5.89$ & $1778.79 \pm 39.63$ & $59.31 \pm 2.11$ & $42.38 \pm 1.26$ & $3 \pm 0.11$ \\
\hline Leonurus japonicus & $82.62 \pm 1.53$ & $848.36 \pm 17.01$ & $214.72 \pm 4.97$ & $40.24 \pm 1.49$ & $47.03 \pm 1.45$ & $2.57 \pm 0.11$ \\
\hline Ligustrum lucidum & $16.51 \pm 0.86$ & $250.49 \pm 14.17$ & $72.87 \pm 4.76$ & $9.43 \pm 0.99$ & $0.4 \pm 0.03$ & $1.41 \pm 0.15$ \\
\hline Lobelia chinensis & $9.37 \pm 0.75$ & $236.66 \pm 20.53$ & $124.26 \pm 12.44$ & $2.26 \pm 0.36$ & $0.64 \pm 0.09$ & $1.2 \pm 0.2$ \\
\hline Lysinachia christinae & $68.01 \pm 1.31$ & $461.07 \pm 9.61$ & $22.96 \pm 0.55$ & $16.46 \pm 0.63$ & $27.88 \pm 0.89$ & $1.12 \pm 0.04$ \\
\hline Paeonia lactiflora & $2.89 \pm 0.12$ & $130.61 \pm 5.95$ & $147.3 \pm 7.75$ & $9.73 \pm 0.82$ & $-0.11 \pm-0.01$ & $0.13 \pm 0.01$ \\
\hline Paeonia suffuticosa & $2.42 \pm 0.10$ & $59.72 \pm 2.81$ & $29.38 \pm 1.59$ & $4.1 \pm 0.36$ & $0.57 \pm 0.04$ & $0.07 \pm 0.01$ \\
\hline Paris polyphylla & NA & NA & NA & NA & NA & NA \\
\hline Platycodon grandiflorus & $12.73 \pm 0.96$ & $180.17 \pm 14.78$ & $56.28 \pm 5.33$ & $12.41 \pm 1.88$ & $0.83 \pm 0.11$ & $1.39 \pm 0.22$ \\
\hline Plantago asiatica & $59.58 \pm 1.23$ & $298.09 \pm 6.68$ & $238.28 \pm 6.16$ & $8.67 \pm 0.36$ & $14.63 \pm 0.5$ & $1.29 \pm 0.06$ \\
\hline Pleione bulbocadioides & NA & NA & NA & NA & NA & NA \\
\hline Ploygala tenuifolia & $21.61 \pm 1.31$ & $43.25 \pm 2.84$ & $47.82 \pm 3.62$ & $5.53 \pm 0.67$ & $0.65 \pm 0.07$ & $0.2 \pm 0.03$ \\
\hline Polygonum aviculare & $34.48 \pm 0.98$ & $294.6 \pm 9.09$ & $5.89 \pm 0.21$ & $36.32 \pm 2.07$ & $9.81 \pm 0.47$ & $0.77 \pm 0.05$ \\
\hline Poria cocos & $230.2 \pm 1.16$ & $1841.43 \pm 10.09$ & $1257.65 \pm 7.95$ & $7.53 \pm 0.08$ & $0.52 \pm 0$ & $3.75 \pm 0.04$ \\
\hline Pogostemon cablin & $64.71 \pm 2.11$ & $565.31 \pm 17.51$ & $392.13 \pm 13.76$ & $83.3 \pm 4.26$ & $5.81 \pm 0.27$ & $4.66 \pm 0.37$ \\
\hline Prunella vulgaris & $9.76 \pm 0.26$ & $128.12 \pm 3.7$ & $522.57 \pm 17.4$ & $14.98 \pm 0.8$ & $17.68 \pm 0.79$ & $0.45 \pm 0.03$ \\
\hline Pseudostellaria heterophylla & $3.53 \pm 0.18$ & $274.37 \pm 15.37$ & $270.58 \pm 17.48$ & $4.19 \pm 0.43$ & $1.1 \pm 0.10$ & $0.36 \pm 0.04$ \\
\hline Rabdosia rubescens & $52.69 \pm 1.25$ & $284.29 \pm 7.30$ & $692.42 \pm 20.5$ & $62.03 \pm 2.94$ & $8.54 \pm 0.34$ & $5.21 \pm 0.26$ \\
\hline Rehmannia glutinosa & $6.86 \pm 0.82$ & $110.9 \pm 14.37$ & $6.61 \pm 0.99$ & $1.46 \pm 0.35$ & $0.55 \pm 0.11$ & $0.08 \pm 0.02$ \\
\hline Salvia miltiorrhiza & $14.45 \pm 1.12$ & $66.17 \pm 5.54$ & $76.18 \pm 7.35$ & $23.83 \pm 3.68$ & $0.51 \pm 0.07$ & $0.13 \pm 0.02$ \\
\hline Sanguisorba officinalis & $74.89 \pm 1.09$ & $909.37 \pm 14.34$ & $274.25 \pm 4.99$ & $25.66 \pm 0.75$ & $4.06 \pm 0.1$ & $1.2 \pm 0.04$ \\
\hline Schizandra chinensis & $5.27 \pm 0.35$ & $168.34 \pm 12.17$ & $543.02 \pm 45.31$ & $13.4 \pm 1.79$ & $0.35 \pm 0.04$ & $0.54 \pm 0.07$ \\
\hline Scutellaria barbata & $45.27 \pm 0.56$ & $290.33 \pm 3.92$ & $634.07 \pm 9.87$ & $58.94 \pm 1.47$ & $3.08 \pm 0.06$ & $1.11 \pm 0.03$ \\
\hline Semen coicis & $91.28 \pm 1.07$ & $367.05 \pm 4.65$ & $367.84 \pm 5.38$ & $28.46 \pm 0.67$ & $5 \pm 0.11$ & $6.97 \pm 0.17$ \\
\hline Smilax glabra & NA & NA & NA & NA & NA & NA \\
\hline Solanum nigrum & $71.07 \pm 2.01$ & $404.88 \pm 12.4$ & $244.61 \pm 8.64$ & $57.18 \pm 3.23$ & $4.83 \pm 0.23$ & $4.46 \pm 0.26$ \\
\hline Solanum lyratum & $74.33 \pm 1.86$ & $596.51 \pm 16.14$ & $9.22 \pm 0.29$ & $11.98 \pm 0.6$ & $0.89 \pm 0.04$ & $0.45 \pm 0.02$ \\
\hline Spatholobus suberectus & $27.63 \pm 0.56$ & $188.26 \pm 4.1$ & $1211.85 \pm 30.48$ & $3.27 \pm 0.13$ & $16.65 \pm 0.56$ & $0.41 \pm 0.02$ \\
\hline
\end{tabular}


Table 3 The trace metal content of water extracts of selected medicinal plants (Continued)

\begin{tabular}{|c|c|c|c|c|c|c|}
\hline Tussilago farfara & $10.16 \pm 0.84$ & $96.79 \pm 8.71$ & $17.52 \pm 1.82$ & $2.13 \pm 0.35$ & $1.87 \pm 0.26$ & $0.18 \pm 0.03$ \\
\hline Uncaria rhyncophylla & $8.25 \pm 0.25$ & $400.03 \pm 12.95$ & $2770.85 \pm 103.53$ & $7.91 \pm 0.47$ & $17.28 \pm 0.86$ & $0.19 \pm 0.01$ \\
\hline Viscum coloratum & $24.77 \pm 0.97$ & $977.52 \pm 41.43$ & $392.4 \pm 19.19$ & $16.65 \pm 1.3$ & $4 \pm 0.26$ & $0.4 \pm 0.03$ \\
\hline
\end{tabular}

NA: not applicable.

* Trace metal contents are expressed in $\mu \mathrm{g} / \mathrm{g}$ of dry plant samples.

\# Mg content was measured in $\mathrm{mg} / \mathrm{g}$.

barbata, P. asiatica, Pogostemonss cablin, P. suffuticosa, $H$. diffusa, L. japonicus, A. paniculata, L. christinae, D. indica, $U$. rhyncophylla and $R$. rubescens have down regulated NO production with $\mathrm{IC}_{50}$ values of less than $0.1 \mathrm{mg} / \mathrm{mL}$ without significantly affecting the cell viability (> 80). Results (Table 4) also revealed that the inhibition efficiency of plant extracts with respect to $\mathrm{NO}$ production was superior when compared to that of TNF- $\alpha$ production. Amongst all the plants, S. officinalis $\left(\mathrm{IC}_{50}=0.07 \mathrm{mg} / \mathrm{mL}\right), P$. asiatica $\left(\mathrm{IC}_{50}=0.1 \mathrm{mg} / \mathrm{mL}\right)$ and $A$. paniculata $\left(\mathrm{IC}_{50}=0.1 \mathrm{mg} / \mathrm{mL}\right)$ have displayed greater inhibition of TNF- $\alpha$ production as well as significant down regulation of $\mathrm{NO}$ production and showed less toxicity.

In order to understand the relationship between the antioxidant activities and polyphenolic content (total phenolics and flavonoids), the selected 44 herbs have been classified into two groups based on the correlation between antioxidant activity and polyphenol content. The first group (consisting of fifteen plants) displayed good relationship between total phenolics / flavonoids content and antioxidant activities (Table 5 and Figure 1). The remaining plants are classified as the second group which did not show a clear correlation between the antioxidant activity and their polyphenol content. The correlation between the DPPH scavenging activity and the total phenolics and flavonoids content of water extracts of the first group of fifteen plants was found to be highly significant (Figure $1 \mathrm{~A}$ and $1 \mathrm{~B}$ ). Similar correlation was also observed for their ethanol extracts (Figure 1C and 1D). The correlations observed in this study, for the first group of plants, are in good agreement with the literature reports that the polyphenolics are the major antioxidant compounds in medicinal plants [1,6-10,47-50].

However, it should be noted that the antioxidant activities of the second group of plants did not show a good correlation between the antioxidant activity and their polyphenol content (Table 2). For example, $V$. coloratum, $H$. diffusa, L. japonicus, A. paniculata and P. lactiflora have displayed high antioxidant activity in both water and ethanol extracts, but contained low levels of phenolics and flavonoids. Similar findings were recently reported by the authors in a separate publication [6]. These observations demonstrate that, in addition to polyphenols, other constituents such as trace metals contribute to the antioxidant activities of medicinal plants. Indeed, a closer observation of the results for the second group of herbs (Tables 2 and 3) indicate that their antioxidant activities are due to the combination of polyphenols and trace metal contents. The results presented in Table 3, revealed that the second group of plants possess significant levels of trace metals. For instance, $V$. coloratum, has low levels of phenolics and flavonoids content but contains high levels of $\mathrm{Zn}, \mathrm{Mn}$ and $\mathrm{Mg}$ (Table 3). This is in agreement with the literature that $\mathrm{Zn}$ and $\mathrm{Mg}$ play crucial role in antioxidant mechanisms [51-53]. Similarly, H. diffusa, L. japonicus, A. paniculata showed good antioxidant activity with high levels of $\mathrm{Zn}$, $\mathrm{Mg}, \mathrm{Mn}$ and Se. In many organisms, trace metals have been shown to act as co-factors of several antioxidant enzymes such as superoxide dismutase (SOD), peroxidases (POD), ascorbate peroxidase (APX) and other enzymes of ascorbate - glutathione pathway [54]. Therefore, the results obtained in this study strongly support trace metal involvement in antioxidant mechanisms. It is therefore hypothesized that the medicinal herbs display their antioxidant activities due to the combination of their total phenolics, flavonoids and the trace metal contents. Some of the plants investigated in this research possessed average levels of all these classes of antioxidants (phenolics, flavonoids and trace metals) and displayed significant antioxidant activities (Tables 2 and 3).

In order to obtain a comprehensive picture on the correlation of the observed activity and the content, all the active plants from Table 2 are considered and their activities are correlated in terms of the three active constituents (total phenolics, flavonoids and trace metals). A diagrammatic visualization scheme has been developed for this purpose which is presented in Figure 2. A brief description of this visualization scheme is given below.

All the plants with high DPPH scavenging activities ( $>120$ Ascorbate equivalent / g) have been included in the "Circle A" of Figure 2. However, the plants included in "Circle B" not only have high scavenging activity but also contain significant quantity of one or more antioxidant constituents (phenolics, flavonoids or trace metals). This automatically means that the plants in "Circle B" are a subset of plants in "Circle A". Circles C, D and E represent the plants with medium to high quantities of phenolics, flavonoids and trace metals respectively (Tables 2 and 3). Any plant that exists in "Circle A" and also is present in one or 
Table 4 Anti-inflammatory activities of water extracts of the selected plants

\begin{tabular}{|c|c|c|c|c|}
\hline Name of the plants & $\begin{array}{l}\mathrm{IC}_{50} \text { for the inhibition of } \\
\mathrm{NO} \text { production }(\mathrm{mg} / \mathrm{ml})\end{array}$ & $\begin{array}{l}\text { Cell viability } \\
(\% \text { of cell survival })^{\&}\end{array}$ & $\begin{array}{l}\mathrm{IC}_{50} \text { for the inhibition of } \\
\text { TNF-a production }(\mathrm{mg} / \mathrm{ml})\end{array}$ & $\begin{array}{l}\text { Cell viability } \\
\text { (\% of cell survival) }^{\&}\end{array}$ \\
\hline Acanthopanax senticosus & $0.12 \pm 0.08$ & $93.85 \pm 8.7$ & $1.23 \pm 0$ & $106.80 \pm 11.6$ \\
\hline Actinidia arguta & $0.07 \pm 0.01$ & $90.3 \pm 1.6$ & $0.73 \pm 0.25$ & $83.05 \pm 4.6$ \\
\hline Akebia quinata & $0.43 \pm 0.05$ & $105.5 \pm 7.8$ & $1.63 \pm 0.4$ & $84.5 \pm 19$ \\
\hline Alpinae officinarum & $0.12 \pm 0.01$ & $92.80 \pm 5.1$ & $0.50 \pm 0$ & $85.55 \pm 13.4$ \\
\hline Andrographis paniculata & $0.05 \pm 0.01$ & $85.20 \pm 6.6$ & $0.10 \pm 0$ & $77.60 \pm 7.2$ \\
\hline Artemisia vulgaris & $0.05 \pm 0$ & $93.2 \pm 6.6$ & $0.21 \pm 0.03$ & $70.7 \pm 0.6$ \\
\hline Asparagus cochinchinensis & $1.49 \pm 1.04$ & $98.35 \pm 3.7$ & $>2.5$ & NA \\
\hline Aster tataricus & $0.14 \pm 0.08$ & $98.95 \pm 1.5$ & $2.30 \pm 0.09$ & $99.70 \pm 0.5$ \\
\hline Corydalis yanhusuo & $0.10 \pm 0.01$ & $70.70 \pm 9.8$ & $0.92 \pm 0.05$ & $62.70 \pm 1.6$ \\
\hline Curcuma zedoaria & $0.25 \pm 0.02$ & $81.1 \pm 8$ & $1.79 \pm 0.23$ & $72.2 \pm 1.5$ \\
\hline Cynanchum paniculatum & $0.24 \pm 0.29$ & $96.5 \pm 1.1$ & $N A^{\#}$ & NA \\
\hline Cyperus rotundus & $0.35 \pm 0.37$ & $86.60 \pm 19$ & $2.39 \pm 0.64$ & $107.50 \pm 10.6$ \\
\hline Ducheshea indica & $0.04 \pm 0.02$ & $100.6 \pm 1.2$ & $0.38 \pm 0$ & $73.95 \pm 2.1$ \\
\hline Hedyotis diffusa & $0.05 \pm 0.00$ & $85.60 \pm 0$ & $0.70 \pm 0.08$ & $57.30 \pm 3.1$ \\
\hline Leonurus japonicus & $0.04 \pm 0.00$ & $78.35 \pm 6.2$ & $0.18 \pm 0.11$ & $62.00 \pm 2.5$ \\
\hline Ligustrum lucidum & $0.14 \pm 0.13$ & $88.8 \pm 15.8$ & $0.3 \pm 0.11$ & $85.6 \pm 20.4$ \\
\hline Lobelia chinensis & $0.36 \pm 0.32$ & $91.5 \pm 13.5$ & 1.67 & $51.3 \pm 68.9$ \\
\hline Lysinachia christinae & $0.06 \pm 0.00$ & $88.50 \pm 0$ & $0.85 \pm 0.14$ & $68.90 \pm 3.1$ \\
\hline Paeonia lactiflora & $0.30 \pm 0.02$ & $92.80 \pm 1$ & $1.07 \pm 0.11$ & $72.15 \pm 0.5$ \\
\hline Paeonia suffuticosa & $0.09 \pm 0.00$ & $90.30 \pm 5.7$ & $0.64 \pm 0.09$ & $63.10 \pm 3.1$ \\
\hline Paris polyphylla & $0.13 \pm 0.06$ & $91.35 \pm 6.2$ & $0.30 \pm 0.40$ & $67.1 \pm 1.6$ \\
\hline Platycodon grandiflorus & $0.43 \pm 0.08$ & $83.05 \pm 3.6$ & $1.79 \pm 0.11$ & $59.45 \pm 2.1$ \\
\hline Plantago asiatica & $0.05 \pm 0.00$ & $81.9 \pm 0$ & 0.1 & $70 \pm 8.7$ \\
\hline Pleione bulbocadioides & $0.58 \pm 0.39$ & $101.5 \pm 0.7$ & $1.59 \pm 0.22$ & $98.6 \pm 2.0$ \\
\hline Ploygala tenuifolia & $0.10 \pm 0.08$ & $89.55 \pm 13.8$ & $0.67 \pm 0.05$ & $52.55 \pm 12.8$ \\
\hline Polygonum aviculare & $0.23 \pm 0.26$ & $87.0 \pm 9.20$ & 0 & NA \\
\hline Poria cocos & $0.34 \pm 0.01$ & $85.9 \pm 9.8$ & 0 & NA \\
\hline Pogostemon cablin & $0.07 \pm 0.00$ & $90.65 \pm 9.3$ & $0.42 \pm 0.22$ & $67.80 \pm 0.6$ \\
\hline Prunella vulgaris & $0.12 \pm 0.11$ & $93.90 \pm 6.6$ & $2.38 \pm 0.4$ & $94.20 \pm 4$ \\
\hline Pseudostellaria heterophylla & $1.06 \pm 0.41$ & $109.0 \pm 12.7$ & $>2.5$ & NA \\
\hline Rabdosia rubescens & $0.05 \pm 0.01$ & $90.65 \pm 2.1$ & $0.36 \pm 0.08$ & $65.60 \pm 2.5$ \\
\hline Rehmannia glutinosa & $1.05 \pm 0.92$ & $91.70 \pm 11.7$ & $>2.5$ & NA \\
\hline Salvia miltiorrhiza & $0.20 \pm 0.05$ & $95.35 \pm 4.6$ & $0.90 \pm 0.06$ & $62.00 \pm 7.6$ \\
\hline Sanguisorba officinalis & $0.03 \pm 0.01$ & $84.2 \pm 5.2$ & $0.07 \pm 0.01$ & $72.6 \pm 2.1$ \\
\hline Schizandra chinensis & $0.27 \pm 0.32$ & $88.05 \pm 16.9$ & $2.31 \pm 0.09$ & $107.65 \pm 11.8$ \\
\hline Scutellaria barbata & $0.05 \pm 0.03$ & $98.2 \pm 2.5$ & 0.6 & $80.5 \pm 20.5$ \\
\hline Semen coicis & $0.63 \pm 0.03$ & $95.40 \pm 5.7$ & $1.17 \pm 0.22$ & $94.60 \pm 5.7$ \\
\hline Smilax glabra & $0.36 \pm 0.38$ & $92.7 \pm 13.2$ & $2.35 \pm 0.22$ & $104.5 \pm 6.4$ \\
\hline Solanum nigrum & 0 & NA & $1.24 \pm 0.2$ & $67.5 \pm 2.1$ \\
\hline Solanum lyratum & $0.49 \pm 0.02$ & $107.5 \pm 10.6$ & $1.68 \pm 0.89$ & $75.4 \pm 7.2$ \\
\hline Spatholobus suberectus & $0.06 \pm 0.02$ & $96.8 \pm 1.6$ & $0.2 \pm 0.04$ & $82.3 \pm 15.8$ \\
\hline
\end{tabular}


Table 4 Anti-inflammatory activities of water extracts of the selected plants (Continued)

\begin{tabular}{|c|c|c|c|c|}
\hline Tussilago farfara & $0.33 \pm 0.24$ & $101.0 \pm 1.4$ & $>2.5$ & NA \\
\hline Uncaria rhyncophylla & $0.05 \pm 0.02$ & $98.80 \pm 1.7$ & $0.45 \pm 0.05$ & $92.90 \pm 11.5$ \\
\hline Viscum coloratum & $0.43 \pm 0.16$ & $89.20 \pm 8.2$ & $2.46 \pm 0$ & $104.50 \pm 6.4$ \\
\hline
\end{tabular}

NA: Not analyzed.

${ }^{\&}$ Cell viability was measured at appropriate $\mathrm{IC}_{50}$ values corresponding to the inhibition of NO and TNF-a.

more of the "Circles C, D or E" will be transferred into "Circle B". Overlaps between antioxidant content circles $(\mathrm{C}, \mathrm{D}, \mathrm{E})$ and antioxidant activity circle (B) represent the activities with respect to the corresponding constituents. As can be seen from Figure 2, the plants are active due to the presence of one or more out of the three active constituents. Some of the plants exhibit their activity due to the presence of all of the three antioxidant constituents (phenolics, flavonoids or trace metals). For instance, the plants $R$. rubescens, S. officinalis, S. suberectus and U. rhyncophylla have displayed their activities due to the presence of significant quantities of all the three antioxidant constituents (Figure 2). These findings further support the hypothesis that the medicinal herbs display their antioxidant activities due to the combination of their total phenolics, flavonoids and the trace metal contents. It should be noted here that only water extracts are considered in Figure 2.
It may be concluded from the above visualization scheme that the activities of 26 out of the 28 active plants could be explained in terms of their antioxidant content. Two of the plants, namely, C. paniculatum and $P$. lactiflora have displayed high antioxidant activities but did not contain significant quantities of any of the antioxidant constituents (Table 2 and Figure 2). One of the reasons for this non-correlation is likely to be due to the fact that some of the polyphenols may be extremely active owing to their structural characteristics even if they are present in smaller quantities [1]. Other reason includes the occurrence of antioxidant constituents (such as polysaccharides) that are not investigated in this study. Several studies demonstrated that botanical polysaccharides possess strong antioxidant activities [55-57].

Significant anti-inflammatory activities were observed for majority of the medicinal herbs studied here

Table 5 The total phenolics and flavonoids content together with the antioxidant activity of fifteen medicinal plants (first group of plants) \#

\begin{tabular}{|c|c|c|c|c|c|c|c|c|}
\hline \multirow[b]{2}{*}{ S. No } & \multirow[b]{2}{*}{ Name of the plants } & \multicolumn{2}{|c|}{$\begin{array}{l}\text { DPPH scavenging activity } \\
\left(\mu \mathrm{M} \text { ascorbate equiv/g) }{ }^{1}\right.\end{array}$} & \multirow[b]{2}{*}{$\begin{array}{l}\% \text { inhibition of } \\
\text { Yeast oxidation of } \\
\text { water extracts }^{2}\end{array}$} & \multicolumn{2}{|c|}{$\begin{array}{l}\text { Phenolics results } \\
(\text { GAE } \mathrm{mg} / \mathrm{g})^{3}\end{array}$} & \multicolumn{2}{|c|}{$\begin{array}{l}\text { Flavonoids results } \\
(\mathrm{QE} \mathrm{mg} / \mathrm{g})^{3}\end{array}$} \\
\hline & & $\begin{array}{l}\text { Water } \\
\text { extracts }\end{array}$ & $\begin{array}{l}\text { Ethanol } \\
\text { extracts }\end{array}$ & & $\begin{array}{l}\text { Water } \\
\text { extracts }\end{array}$ & $\begin{array}{l}\text { Ethanol } \\
\text { extracts }\end{array}$ & $\begin{array}{l}\text { Water } \\
\text { extracts }\end{array}$ & $\begin{array}{l}\text { Ethanol } \\
\text { extracts }\end{array}$ \\
\hline 1 & Semen coicis & $-100.1 \pm 0.71$ & $11.00 \pm 3.54$ & 12.37 & $0.34 \pm 2.32$ & $1.39 \pm 0.65$ & $0.83 \pm 1.96$ & $16.05 \pm 2.93$ \\
\hline 2 & Pogostemon cablin & $103.4 \pm 4.24$ & $26.00 \pm 1.52$ & 12.07 & $4.23 \pm 0.68$ & $1.88 \pm 0.13$ & $5.54 \pm 0.98$ & $4.08 \pm 0.98$ \\
\hline 3 & Pseudostellaria heterophylla & $20.9 \pm 12.02$ & $32.43 \pm 4.55$ & 36.13 & $1.74 \pm 0.82$ & $1.58 \pm 1.83$ & $0.59 \pm 0.00$ & $1.94 \pm 0.98$ \\
\hline 4 & Paeonia suffuticosa & $200.4 \pm 0.00$ & $111.71 \pm 0.51$ & 15.16 & $19.96 \pm 1.09$ & $19.74 \pm 0.39$ & $25.85 \pm 1.96$ & $31.40 \pm 2.93$ \\
\hline 5 & Corydalis yanhusuo & $39.9 \pm 0.71$ & $42.43 \pm 5.56$ & 14.81 & $3.51 \pm 1.36$ & $1.28 \pm 1.48$ & $1.57 \pm 0.96$ & $2.11 \pm 0.98$ \\
\hline 6 & Ploygala tenuifolia & $109.4 \pm 2.83$ & $53.14 \pm 2.53$ & 3.23 & $12.01 \pm 0.00$ & $12.15 \pm 0.44$ & $9.3 \pm 3.91$ & $37.55 \pm 3.91$ \\
\hline 7 & Ducheshea indica & $202.4 \pm 1.41$ & $102.07 \pm 4.04$ & 2.34 & $28.62 \pm 0.68$ & $11.8 \pm 0.44$ & $22.31 \pm 4.89$ & $15.25 \pm 1.96$ \\
\hline 8 & Asparagus cochinchinensis & $55.9 \pm 12.02$ & $5.64 \pm 1.01$ & 16.37 & $2.67 \pm 0.96$ & $0.91 \pm 3.01$ & $1.71 \pm 0.98$ & $1.08 \pm 0.98$ \\
\hline 9 & Tussilago farfara & $198.9 \pm 0.71$ & $113.5 \pm 0.00$ & 20.9 & $25.72 \pm 2.87$ & $9.68 \pm 0.15$ & $65.17 \pm 0.98$ & $41.67 \pm 0.98$ \\
\hline 10 & Aster tataricus & $119.4 \pm 2.83$ & $49.93 \pm 2.02$ & 0 & $15.17 \pm 0.27$ & $6.95 \pm 0.00$ & $39.82 \pm 0.98$ & $22.79 \pm 0.98$ \\
\hline 11 & Rabdosia rubescens & $144.4 \pm 2.83$ & $13.50 \pm 4.04$ & 8.63 & $17.47 \pm 0.55$ & $2.41 \pm 2.96$ & $40.66 \pm 1.96$ & $8.35 \pm 2.93$ \\
\hline 12 & Platycodon grandiflorus & $30.9 \pm 3.54$ & $14.93 \pm 4.04$ & 21.77 & $4.58 \pm 1.50$ & $0.79 \pm 0.26$ & $2.93 \pm 2.93$ & $1.52 \pm 0.96$ \\
\hline 13 & Artemisia vulgaris & $181.9 \pm 0.71$ & $98.14 \pm 1.52$ & 5.32 & $24.91 \pm 0.27$ & $7.43 \pm 1.44$ & $79.68 \pm 1$ & $16.43 \pm 3.91$ \\
\hline 14 & Ligustrum lucidum & $194.9 \pm 0.71$ & $107.79 \pm 0$ & 12.02 & $29.1 \pm 3.28$ & $19 \pm 0.78$ & $108.42 \pm 1.96$ & $24.88 \pm 0.98$ \\
\hline 15 & Scutellaria barbata & $188.4 \pm 1.41$ & $93.5 \pm 1.01$ & 10.11 & $14.97 \pm 2.73$ & $9.26 \pm 0.15$ & $67.41 \pm 3.91$ & $20.62 \pm 0.98$ \\
\hline
\end{tabular}

${ }^{1} \mathrm{DPPH}$ free radical scavenging activity was measured in terms of equivalent of ascorbate $(\mu \mathrm{M})$.

${ }^{2}$ Yeast oxidative stress was measured on the basis of survival of yeast cells (yeast growth) after treatment with $\mathrm{H}_{2} \mathrm{O}_{2}$.

${ }^{3}$ Total phenolics and flavonoid contents were expressed in gallic acid equivalent (GAE $\mathrm{mg} / \mathrm{g}$ ) and quercetin equivalent (QE mg/g) respectively.

\# Plants given in this table show significant correlation between their antioxidant activities and total phenolics / flavonoids contents. These plants are a subset of plants studied in this research (Table 1). 


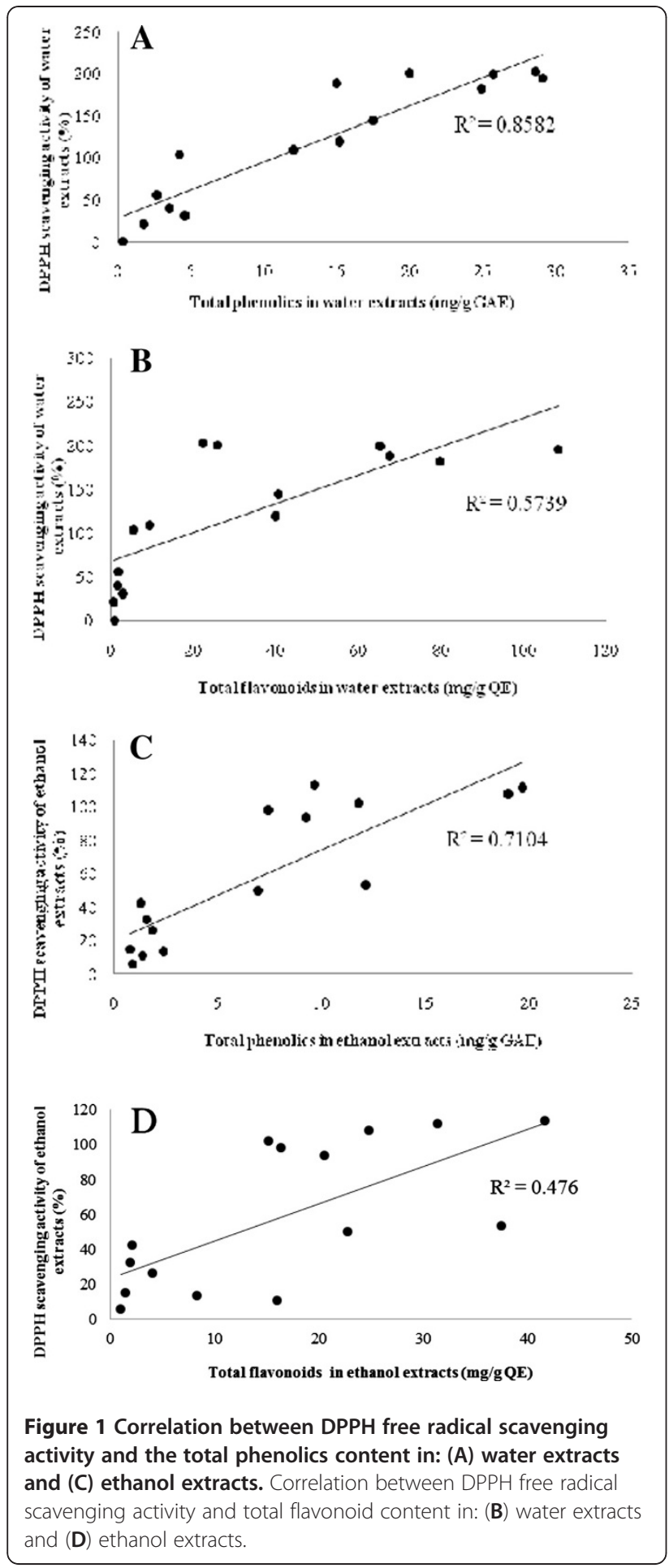

(Table 4). For instance, S. officinalis, D. indica, P. suffuticosa, $U$. rhyncophylla and $R$. rubescens have inhibited $\mathrm{NO} / \mathrm{TNF}-\alpha$ with low $\mathrm{IC}_{50}$ values and also contain high phenolics and flavonoids content. Bioactive molecules isolated in the literature from some of these plants showed significant anti-inflammatory properties $[58,59]$.

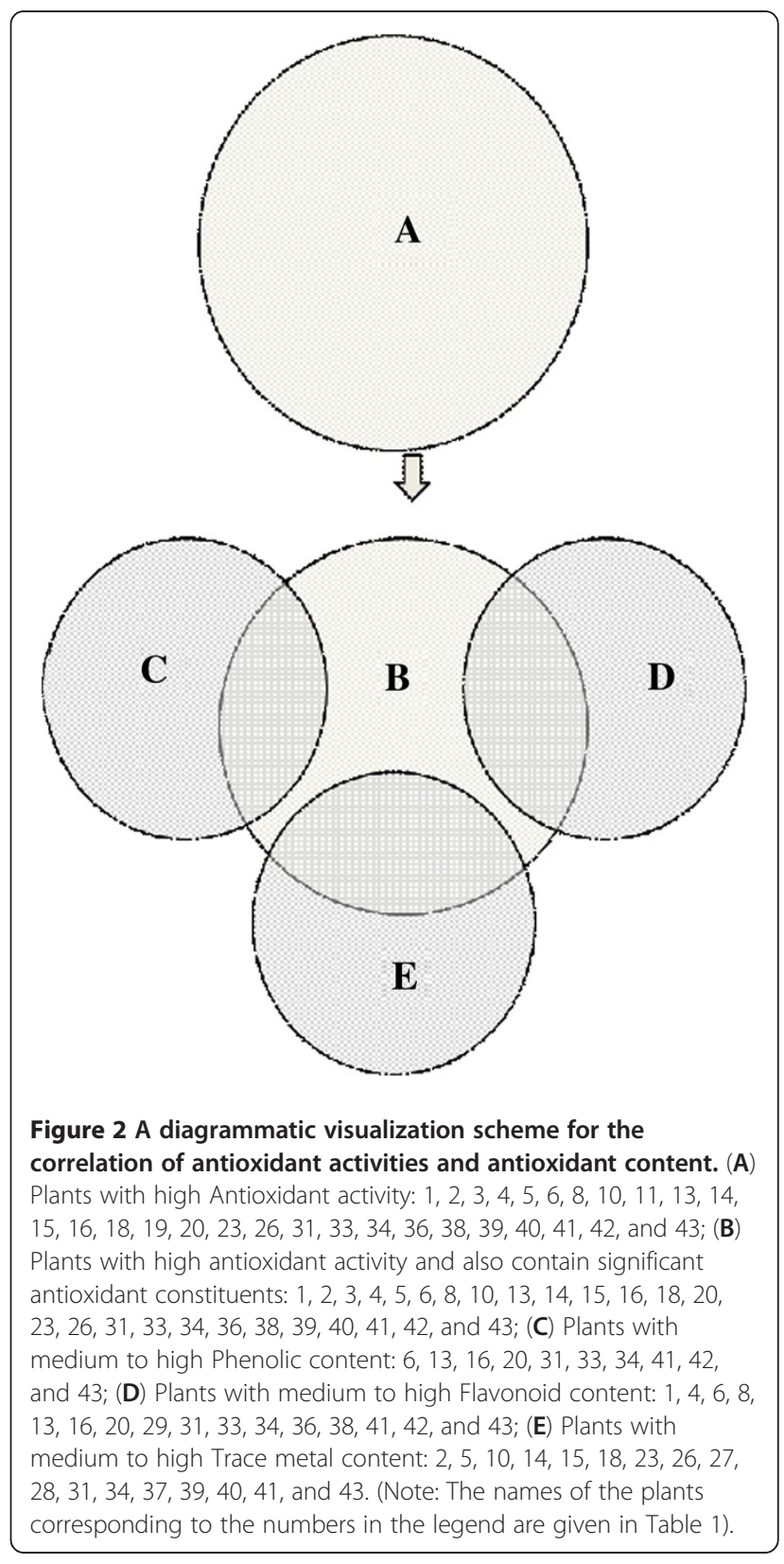

For example, Sanguiin H-6 and H-11 isolated from S. officinalis has decreased the expression levels of iNOS [58]. Rhyncophylline and isorhyncophylline are isomeric alkaloids from $U$. rhyncophylla showed inhibition activity against the NO production and proinflammatory cytokines such as TNF- $\alpha$ and IL- $1 \beta$ production in LPS induced mouse N9 microglial cells [59].

\section{Conclusions}

Forty-four selected medicinal plants have been investigated in this study for their antioxidant and antiinflammatory activities. Amongst these plants, two distinct groups have been identified in terms of the 
correlation of antioxidant activities and their antioxidant contents. First group exhibited good relationship between total phenolics / flavonoids content and antioxidant activity, whilst in the second group such a relationship was poor. The observed biological activities of all the plants including those in the second group, could clearly be explained when trace metal content was considered together with polyphenols content. Amongst all the selected plants, L. lucidum, P. suffuticosa, S. miltiorrhiza, S. officinalis, S. suberectus, T. farfara and U.rhyncophylla showed significant antioxidant and anti-inflammatory activities with very low toxic effects. Consequently, the isolation of bioactive compounds from these target plants is underway in our laboratory.

\section{Competing interests}

The authors declare that they have no competing interests.

\section{Authors' contributions}

ASR, LZ, KS, MJU and MS have performed the experiments and analysis. ASR and LZ have contributed to the manuscript preparation. SRK and NR have designed the study, contributed to the analysis, critically evaluated the paper and provided the final manuscript. SJ helped with the preparation samples. PTS, BV, GM and JB have contributed to the manuscript preparation. All authors read and approved the final manuscript.

\section{Author details}

'School of Science and Health, Locked Bag 1797, Penrith South DC NSW 1797, Australia. ${ }^{2}$ Centre for Complementary Medicine Research, Locked Bag 1797, Penrith South DC NSW 1797, Australia. ${ }^{3}$ School of Medicine, University of Western Sydney, Locked Bag 1797, Penrith South DC NSW 1797, Australia. ${ }^{4}$ School of Pharmacy and Molecular Sciences, James Cook University, Townsville, Queensland 4811, Australia. ${ }^{5}$ CSIR-National Geophysical Research Institute, Uppal Road, Hyderabad 500007, India.

Received: 11 January 2012 Accepted: 20 September 2012

Published: 6 October 2012

\section{References}

1. Cai Y, Luo Q, Sun M, Corke H: Antioxidant activity and phenolic compounds of 112 traditional Chinese medicinal plants associated with anticancer. Life Sci 2004, 74:2157-2184.

2. Dragland S, Senoo H, Wake K, Holte K, Blomhoff R: Several culinary and medicinal herbs are important sources of dietary antioxidants. J Nutr 2003, 133:1286-1290.

3. Akinmoladun AC, Obuotor EM, Farombi EO: Evaluation of antioxidant and free radical scavenging capacities of some Nigerian indigenous medicinal plants. J Med Food 2010, 13:444-451.

4. Özen T, Çöllü Z, Korkmaz H: Antioxidant Properties of Urtica pilulifera Root, Seed, Flower, and Leaf Extract. J Med Food 2010, 13:1224-1231.

5. Hendra R, Ahmad S, Oskoueian E, Sukari A, Shukor MY: Antioxidant, Antiinflammatory and Cytotoxicity of Phaleria macrocarpa (Boerl.) Scheff Fruit. BMC Complement Altern Med 2011, 11:110.

6. Zhang L, Ravipati AS, Koyyalamudi SR, Jeong SC, Reddy N, Smith PT, Bartlett J, Shanmugam K, Münch DG, Wu MJ: Antioxidant and Anti-inflammatory Activities of Selected Medicinal Plants Containing Phenolic and Flavonoid compounds. J Agric Food Chem 2011, 59:12361-12367.

7. Gülçin I: Antioxidant activity of food constituents: an overview. Arch Toxicol 2012, 86:345-391.

8. Rivero MD, Pérez-Magariño S, González-Sanjosé ML, Valls-Belles V, Codoñer P, Muñiz P: Inhibition of induced DNA oxidative damage by beers: Correlation with the content of polyphenols and melanoidins. J Agric Food Chem 2005, 53:3637-3642.

9. Gião MS, González-Sanjosé ML, Rivero-Pérez MD, Pereira Cl, Pintado ME, Malcata FX: Infusions of Portuguese medicinal plants: dependence of final antioxidant capacity and phenol content on extraction features. J Sci Food Agr 2007, 87:2638-2647.

10. Raudoniūte I, Rovira J, Venskutonis PR, Damašius J, Rivero-Pérez MD, González-SanJosé ML: Antioxidant properties of garden strawberry leaf extract and its effect on fish oil oxidation. Int J Food Sci Tech 2011, 46:935-945.

11. Fraga CG: Relevance, essentiality and toxicity of trace elements in human health. Mol Aspect Med 2005, 26:235-244.

12. Purdey M: Ecosystems supporting clusters of sporadic TSEs demonstrate excesses of the radical-generating divalent cation manganese and deficiencies of antioxidant co factors $\mathrm{Cu}, \mathrm{Se}, \mathrm{Fe}, \mathrm{Zn}$. Med hypotheses 2000, 54:278-306.

13. Talhouk R, Karam C, Fostok S, El-Jouni W, Barbour E: Anti-inflammatory bioactivities in plant extracts. J Med Food 2007, 10:1-10.

14. Lee MS, Yuet-Wa JC, Kong SK, Yu B, Eng-Choon VO, Nai-Ching HW, Chung-Wai TM, Fung KP: Effects of Polyphyllin D, a Steroidal Saponin in, in Growth Inhibition of Human Breast Cancer Cells and in Xenograft. Canc Biol Ther 2005, 4:1248-1254.

15. Wang C, Schuller Levis GB, Lee EB, Levis WR, Lee DW, Kim BS, Park SY, Park E: Platycodin D and D3 isolated from the root of Platycodon grandiflorum modulate the production of nitric oxide and secretion of TNF-[alpha] in activated RAW 264.7 cells. Int J Immunopharmacol 2004, 4:1039-1049.

16. Ou B, Huang D, Hampsch-woodill M, Flanagan J: When east meets west: the relationship between yin-yang and antioxidation-oxidation. The FASEB Journal 2003, 17:127.

17. Prior RL, Guohua C: Antioxidant phytochemicals in fruits and vegetables: Diet and health implications: The role of oxidative stress and antioxidants in plant and human health. Hort Science 2000, 35:588-592.

18. Huang HB, Li KX, Liu T, Zeng CQ, Lin J, Qiu M: Kang Zhong Liu Zhong Yao Lin Chuang Ying Yong Yu Tu Pu (Clinical application of anti-tumor Chinese medicine). Guang Zhou: Guangdong Science and Technology Press; 2008

19. Wu MJ, O'Doherty PJ, Fernandez HR, Lyons V, Rogers PJ, Dawes IW, Higgins VJ: An antioxidant screening assay based on oxidant-induced growth arrest in Saccharomyces cerevisiae. FEMS yeast research 2011, 11:379-387.

20. Moon JK, Shibamoto T: Antioxidant assays for plant and food components. J Agric Food Chem 2009, 57:1655-1666.

21. Dudonneì $S$, Vitrac $X$, Coutielre $P$, Woillez $M$, Meirillon JM: Comparative study of antioxidant properties and total phenolic content of 30 plant extracts of industrial interest using DPPH, ABTS, FRAP, SOD, and ORAC assays. J Agric Food Chem 2009, 57:1768-1774.

22. Han S, Yoon Y, Ahn H, Lee H, Lee C, Yoon W, Park S, Kim H: Toll-like receptor-mediated activation of $B$ cells and macrophages by polysaccharide isolated from cell culture of Acanthopanax senticosus. Int J Immunopharmacol 2003, 3:1301-1312.

23. Fangyu $H$, Fei C, Yi L: Studies on anti infechve and antitumor effects of Actinidia arguta stem polysaccharide (AASP)[J]. J Norman Bethune Uni. Med Sci 1995, 5. doi:CNKI:SUN:BQEB.0.1995-05-017.

24. Ikuta A, Itokawa $\mathrm{H}$ : Triterpenoids of Akebia quinata callus tissue. Phytochemistry 1986, 25:1625-1628.

25. Lee SE, Hwang HJ, Ha JS, Jeong HS, Kim JH: Screening of medicinal plant extracts for antioxidant activity. Life sci 2003, 73:167-179.

26. Ajaya Kumar R, Sridevi K, Vijaya Kumar N, Nanduri S, Rajagopal S: Anticancer and immunostimulatory compounds from Andrographis paniculata. J. Ethnopharmacol 2004, 92:291-295.

27. Sujatha G, Kumari BDR: Effect of phytohormones on micropropagation of Artemisia vulgaris L. Acta Physiologiae Plantarum 2007, 29:189-195.

28. Cho WCS: Supportive cancer care with Chinese medicine. New York: Springer Verlag; 2010.

29. Ng T, Liu F, Lu Y, Cheng C, Wang Z: Antioxidant activity of compounds from the medicinal herb Aster tataricus. Comp Biochem Physiol C Toxicol Pharmacol 2003, 136:109-115.

30. Syu WJ, Shen CC, Don MJ, Ou JC, Lee GH, Sun CM: Cytotoxicity of curcuminoids and some novel compounds from Curcuma zedoaria. J Nat Prod 1998, 61:1531-1534.

31. Zhao L, Zhang SL, Tao JY, Jin F, Pang R, Guo YJ, Ye P, Dong JH, Zheng GH: Anti-inflammatory mechanism of a folk herbal medicine, Duchesnea indica (Andr) Focke at RAW264. 7 cell line. Immunol Investig 2008, 37:339-357. 
32. Tao J, Zhang P, Liu G, Yan H, Bu X, Ma Z, Wang N, Wang G, Jia W: Cytotoxicity of Chinese motherwort (YiMuCao) aqueous ethanol extract is non-apoptotic and estrogen receptor independent on human breast cancer cells. J Ethnopharmacol 2009, 122:234-239.

33. Zhang J, Li L, Kim SH, Hagerman AE, Lü J: Anti-cancer, anti-diabetic and other pharmacologic and biological activities of pentagalloyl-glucose. Pharmaceut Res 2009, 26:2066-2080.

34. Galvez M, Martin-Cordero C, Lopez-Lazaro M, Cortes F, Ayuso MJ: Cytotoxic effect of Plantago spp. on cancer cell lines. J Ethnopharmacol 2003, 88:125-130.

35. Kim H, Lee E, Na H, Lee S, Shin T, Lyu Y, Kim N, Nomura S: Effect of Polygala tenuifolia root extract on the tumor necrosis factor-[alpha] secretion from mouse astrocytes. J Ethnopharmacol 1998, 61:201-208.

36. Hsu CY: Antioxidant activity of extract from Polygonum aviculare L. Biol Res 2006, 39:281-288.

37. Park EJ, Park HR, Lee JS, Kim J: Licochalcone A: an inducer of cell differentiation and cytotoxic agent from Pogostemon cablin. Planta Medica-Natural Products and Medicinal Plant Research 1998, 64:464-465.

38. Feng $L$, Jia XB, Shi F, Chen $Y$ : Identification of two polysaccharides from Prunella vulgaris $\mathrm{L}$. and evaluation on their anti-lung adenocarcinoma activity. Molecules 2010, 15:5093-5103.

39. Hancke JL, Burgos RA, Ahumada F: Schizandra chinensis Turcz. Baill. Fitoterapia 1999, 70:451-471.

40. Kim MR, Lee JY, Lee HH, Aryal DK, Kim YG, Kim SK, Woo ER, Kang KW: Antioxidative effects of quercetin-glycosides isolated from the flower buds of Tussilago farfara L. Food Chem Toxicol 2006, 44:1299-1307.

41. Heitzman ME, Neto CC, Winiarz E, Vaisberg AJ, Hammond GB: Ethnobotany, phytochemistry and pharmacology of Uncaria (Rubiaceae). Phytochemistry 2005, 66:5-29.

42. Hwang TL, Leu YL, Kao SH, Tang MC, Chang HL: Viscolin, a new chalcone from Viscum coloratum, inhibits human neutrophil superoxide anion and elastase release via a CAMP-dependent pathway. Free Radic Biol Med 2006, 41:1433-1441.

43. Cicco N, Lanorte MT, Paraggio M, Viggiano M, Lattanzio V: A reproducible, rapid and inexpensive Folin-Ciocalteu micromethod in determining phenolics of plantmethanol extracts. Microchem J 2009, 91:107-110.

44. Jia ZS, Tang MC, Wu JM: The determination of flavonoid contents in mulberry and their scavenging effects on superoxide radicals. Food Chem 1999, 64:555-559.

45. Blois MS: Antioxidant determinations by the use of a stable free radical. Nature 1958, 181:1199-1200.

46. Shanmugam K, Holmquist L, Steele M, Stuchbury G, Berbaum K, Schulz O, Benavente-Garcia O, Castillo J, Burnell J, Garcia Rivas V, Dobson G, Munch G: Plant-derived polyphenols attenuate lipopolysaccharide-induced nitric oxide and tumour necrosis factor production in murine microglia and macropgages. Mol Nutr Food Res 2008, 52:427-438.

47. Gülçin I, Küfrevioğlu OI, Oktay M, Büyükokuroğlu ME: Antioxidant, antimicrobial, antiulcer and analgesic activities of nettle (Urtica dioica L.). J Ethnopharmacol 2004, 90:205-215.

48. Gulcin I, Tel AZ, Kirecci E: Antioxidant, antimicrobial, antifungal, and antiradical activities of Cyclotrichium niveum (BOISS.). Manden and Scheng. Int J Food Prop 2008, 11:450-471.

49. Rivero-Pérez MD, MUNiz P, González-Sanjosé ML: Antioxidant profile of red wines evaluated by total antioxidant capacity, scavenger activity, and biomarkers of oxidative stress methodologies. J Agri Food Chem 2007, 55:5476-5483.

50. Phillipson J: Phytochemistry and medicinal plants. Phytochemistry 2001, 56:237-243

51. Arnér ESJ, Holmgren A: Physiological functions of thioredoxin and thioredoxin reductase. Eur J Biochem 2000, 267:6102-6109.

52. Cross H, Pepper T, Kearsley M, Birch G: Mineral complexing properties of food carbohydrates. Starch--Stärke 1985, 37:132-135.

53. Ho E: Zinc deficiency, DNA damage and cancer risk. J Nutr Biochem 2004 15:572-578

54. Cartes P, Jara A, Pinilla L, Rosas A, Mora M: Selenium improves the antioxidant ability against aluminium--induced oxidative stress in ryegrass roots. Ann Appl Biol 2010, 156:297-307.
55. Schepetkin IA, Quinn MT: Botanical polysaccharides: macrophage immunomodulation and therapeutic potential. Immunopharmacology 2006, 6:317-333.

56. Minato K: Mushrooms: Immunomodulating Activity and Role in Health Promotion. In Dietary Components and Immune Function. Edited by Watson RR, Zibadi S, Preedy VR. New York: Humana press; 2010:529-539.

57. He XJ, Niu XY, Li J, Xu SH, Lu AP: Immunomodulatory activities of five clinically used Chinese herbal polysaccharides. J Exper Integr Med 2012, 2:15-27.

58. Mimaki Y, Fukushima M, Yokosuka A, Sashida Y, Furuya S, Sakagami H: Triterpene glycosides from the roots of Sanguisorba officinalis. Phytochemistry 2001, 57:773-779.

59. Yuan D, Ma B, Yang J, Xie Y, Wang L, Zhang L, Wu KY: Anti-inflammatory effects of rhynchophylline and isorhynchophylline in mouse N9 microglial cells and the molecular mechanism. Int Immunopharm 2009, 9:1549-1554.

doi:10.1186/1472-6882-12-173

Cite this article as: Ravipati et al.: Antioxidant and anti-inflammatory activities of selected Chinese medicinal plants and their relation with antioxidant content. BMC Complementary and Alternative Medicine 2012 $12: 173$.

\section{Submit your next manuscript to BioMed Central and take full advantage of:}

- Convenient online submission

- Thorough peer review

- No space constraints or color figure charges

- Immediate publication on acceptance

- Inclusion in PubMed, CAS, Scopus and Google Scholar

- Research which is freely available for redistribution 